\title{
When cutting dividends is not bad news: The case of optional stock dividends
}

\author{
Thomas David* \\ Université Paris-Dauphine, DRM \\ Edith Ginglinger** \\ Université Paris-Dauphine, DRM
}

May 2015

\begin{abstract}
:
This paper provides new evidence on dividend policy by studying optional stock dividends, a mechanism that allows firms to cut cash payouts without a negative market reaction. We find that highly leveraged firms with limited cash holdings and large institutional ownership are more likely to offer optional stock dividends to their shareholders. These firms are the most committed to paying dividends, and optional stock dividends provide them with an opportunity for a stealth cut in dividends during economic downturns. Shareholders overwhelmingly approve optional stock dividends at general meetings with the majority favoring stock dividends over cash dividends. Further, in contrast to dividend cuts, shareholders do not view optional stock dividends as bad news. Our results support the monitoring explanation of optional stock dividends and show that shareholders value a firm's ability and willingness to pay dividends, even if the final cash payout is reduced.
\end{abstract}

JEL: G35, G32

Keywords: dividends, stock dividends, scrip dividends, dividend cuts, monitoring, SEOs, long-term investors

* thomas.david@dauphine.fr, ** edith.ginglinger@dauphine.fr, Université Paris-Dauphine, place du Maréchal de Lattre, 75775 Paris cedex 16

The authors thank Daniel Ferreira, Zsuzsanna Fluck, Carole Gresse, Denis Gromb, Jayant Kale, Stefano Lovo, Bill Megginson, Roni Michaely, Manju Puri, Luc Renneboog and Boris Vallee for their comments and suggestions. 


\title{
When cutting dividends is not bad news: The case of optional stock dividends
}

\begin{abstract}
:
This paper provides new evidence on dividend policy by studying optional stock dividends, a mechanism that allows firms to cut cash payouts without a negative market reaction. We find that highly leveraged firms with limited cash holdings and large institutional ownership are more likely to offer optional stock dividends to their shareholders. These firms are the most committed to paying dividends, and optional stock dividends provide them with an opportunity for a stealth cut in dividends during economic downturns. Shareholders overwhelmingly approve optional stock dividends at general meetings with the majority favoring stock dividends over cash dividends. Further, in contrast to dividend cuts, shareholders do not view optional stock dividends as bad news. Our results support the monitoring explanation of optional stock dividends and show that shareholders value a firm's ability and willingness to pay dividends, even if the final cash payout is reduced.
\end{abstract}

JEL: G35, G32

Keywords: dividends, stock dividends, scrip dividends, dividend cuts, monitoring, SEOs, long-term investors 


\section{When cutting dividends is not bad news: The case of optional stock dividends}

\section{Introduction}

Since Lintner (1956), several studies have documented the dividend smoothing phenomena and have reported that managers view dividend stability as one of the most important factors in payout policy. Firms that decrease or omit dividends suffer a severe decline in value (Pettit, 1972 and Aharony and Swary, 1980). Further, based on a survey of executives, Brav, Graham, Harvey, and Michaely (2005) note that "many of the interviewed executives would like to cut dividends but feel constrained by their historic policy. Some of these firms look for opportunities for a stealth cut in dividends.” However, there is little agreement about why firms should smooth their dividends, and Larkin, Leary, and Michaely (2014) find no relationship between firms' dividend smoothing policy and firm value.

This paper provides new evidence on dividend policy by studying optional stock dividends, also called scrip dividends, a mechanism that allows firms to cut cash payouts without a negative market reaction. Since 1983, in France-a major western country with the fifth largest economy in the world and a well-developed corporate sector-firms can offer their shareholders the option to receive dividends in stock rather than in cash. ${ }^{1}$ Optional stock dividends provide a valuable framework to further investigate why firms are reluctant to decrease dividends and which investors prefer a cash payout. Specifically, we address the following questions: First, why do firms use optional stock dividends rather than decrease their dividends? Second, why do firms prefer optional stock dividends to paying a cash dividend and simultaneously raising external capital? Third, are investors willing to receive stock dividends instead of cash dividends? Fourth, how do stock prices react to optional stock dividends? Do shareholders value the option to receive nominal dividends that are accompanied by a voluntary decrease in cash dividends?

In the first part of our empirical analysis, we use a unique dataset to study the relationship between firm characteristics and the three-way choice among cash dividends, optional stock dividends, and dividend cuts. We also perform logit analysis to examine the choice between

\footnotetext{
${ }^{1}$ Optional stock dividends lead to substantial capital increases. For example, Veolia Environnement offered annual optional stock dividends from 2009 to 2014, and its capital has increased by 18\% over the period, allowing the firm to raise 1.18 billion euros. Bouygues offered optional stock dividends for the first time in 2014 (fiscal year 2013), because its BBB+ credit rating was placed on negative watch. Accepted by $79.1 \%$ of shareholders, this option enabled the firm to increase its capital by 5\%. Optional stock dividends exist in several European countries, but the institutional settings differ across countries (with respect to, for example, length of the option, reference price, and tax treatment).
} 
paying optional stock dividends and cutting dividends and the choice between paying optional stock dividends and maintaining cash dividends. In the second part of our analysis, we study the market reaction to optional stock dividend announcements and examine the effects of firm characteristics on the CARs on the announcement day. In an analysis novel to the literature, we examine the shareholder decision to takeup stock dividends and the relation between shareholder takeup and firm characteristics. Studying optional stock dividends allows us to highlight the conditions for shareholders to accept and even value cash dividend cuts. We are thus able to investigate whether flexibility to decrease cash dividends creates shareholder value and under which circumstances value is created.

A number of theoretical models have implications for the choice and consequences of optional stock dividends, which are reviewed in detail in section 3. We examine three hypotheses. First, we predict that the choice of optional stock dividends allows a firm to continue paying dividends when the firm is short of cash or equity. Firms that are the most committed to paying dividends are thus more likely to resort to paying optional stock dividends instead of cutting dividends when they are facing difficult financial times. In contrast to stock repurchases, which are characterized by substantial flexibility for firms, dividends are a commitment to the future. Firms have an implicit contract to distribute cash to shareholders (Myers, 1993). A dividend payout is the preferred payout method when the potential for wasting free cash flow is likely to be high. However, by using dividends rather than repurchases, managers have less freedom to adjust payouts for the firm's investment needs and economic downturns. They lose financial flexibility, the importance of which has been well documented (e.g., Jannagathan, Stephens and Weisbach, 2000). To compensate for the lack of flexibility associated with dividends, firms can issue new equity; however, seasoned equity offerings (SEOs) are costly and dependent on market conditions (Bayless and Chaplinsky, 1996). By choosing optional stock dividends, a firm is committed to paying the total announced dividend, and it must disburse the total amount if all shareholders opt for cash but saves cash if some shareholders opt for stocks.

Second, optional stock dividends are a cheaper way to issue equity rather than using independent SEOs, and they should be used especially during periods of economic downturns when SEOs are rare and when banks are reluctant to take the risk of underwriting them. Optional stock dividends allow firms to issue new shares directly to shareholders without the help of an investment bank (e.g., Scholes and Wolfson, 1989 and Eckbo and Masulis, 1992, for US drips). Hence, they save underwriter fees and avoid the negative signal of a new equity offering, and the discount is comparable to that observed in public offerings in France. This discount is earned 
by current shareholders who opt for stock dividends, whereas it is earned by external investors in public offerings. The direct cost of the stock dividend option therefore appears to be comparable to or lower than the cost of underwritten offerings.

Third, optional stock dividends may have implications for the ownership structure of firms and may trigger wealth effects for current shareholders. According to Brennan and Thakor's (1990) model for the choice between repurchases and dividends, better-informed shareholders may be able to take advantage of their superior information to opt for stock when it is worth more than the offer price and to opt for cash when it is worth less. Because of the fixed cost of collecting information, large shareholders should be more willing than small shareholders to choose stock dividends. Optional stock dividends can also be viewed as a mechanism that can help managers increase the percentage ownership of shareholders with high valuation of their firm (e.g., Ang and Kraizberg, 2004), as such high valuation shareholders are more likely to be long-term shareholders. Several studies show that investor horizons are important for financial decisions (for example, Bushee, 1998, Graham, Harvey and Rajgopal, 2005, Derrien, Kecskes and Thesmar, 2013). According to these views, the takeup of stock in optional stock dividends should increase with the fraction of the capital owned by informed and/or long-term shareholders, either blockholders or institutional investors.

In this paper, we use a hand-collected dataset of 288 French firms for the 2003-2012 period (2729 firm-years) to analyze the decision to pay optional stock dividends in a tax-neutral environment. First, we find that mature, highly leveraged firms with a liquid stock market and a large percentage of their capital held by institutional investors offer optional stock dividends to their shareholders when they are short of cash. These firms are the most committed to paying dividends, and optional stock dividends provide them with an opportunity for a stealth cut in dividends during economic downturns. By contrast, firms with large blockholders, who are known to be effective monitors, less frequently use the option to pay dividends in stock. These results support the monitoring hypothesis: firms that are the most subject to the agency costs of free cash flows are the most likely to use optional stock dividends to maintain nominal dividends.

Second, we find that optional stock dividends are used primarily during recession periods, when SEOs are expensive and are associated with a large discount. Offering optional stock dividends resembles a small rights issue with nontransferable rights, as only current shareholders are able to subscribe to new shares and as the capital increase is limited to the subscriptions. Optional stock dividends are therefore a low-cost alternative to SEOs. 
We further investigate how shareholders approve and value optional stock dividends. Optional stock dividends provide us with a unique opportunity to measure the preference of shareholders for stock rather than dividends. Shareholders have to approve the mechanism during the general meeting in which they approve a firm's annual results and dividend payment. The stock dividend option has to be presented and adopted as a specific resolution. Shareholders overwhelmingly approve optional stock dividends at general meetings, and more than half of them volunteer for stock dividends instead of cash dividends. In contrast to dividend cuts, they do not view optional stock dividends as bad news: we document a positive market reaction on the announcement day of optional stock dividends and find that shareholders value nominal dividends as if they were cash dividends for the total amount. Our results suggest that the monitoring effect of optional stock dividends is linked to the commitment to pay dividends and not to the cash payout itself. We further find that the takeup increases with the fraction of capital held by institutional investors, who can be viewed as informed investors, and by blockholders, who can be viewed as long-term investors. These findings suggest that optional stock dividends are offered when a firm's stock is underpriced on the market.

A small body of empirical literature focuses on optional stock dividends. Lasfer (1997) investigates optional stock dividends in the UK over the 1987-1992 period. During this period, stock dividends are not subject to the advanced corporation tax that is payable on cash dividends, and the study results reject the tax motivation for the choice to pay optional stock dividends. Jacquillat (1992) investigates informational effects related to optional stock dividends in France, and Jacquemet (1998) proposes and tests a valuation model for the option to take dividends in stock. However, both papers examine a period that includes several years (1989 to 1992), during which optional stock dividends enjoyed a tax benefit for French firms.

Also related to our study are a few papers that analyze tax motivations for different classes of shares that offer access to either stock or cash dividends but that do not offer options for both. Ang, Blackwell, and Megginson (1991) study British investment trusts with one class of shares entitled only to stock dividends and another class entitled to cash dividends. They find that after the tax advantage of stock dividend shares is eliminated, investors express a preference for cash dividend shares and convert all stock dividend shares into cash dividend shares. Similarly, Hubbard and Michaely (1997) examine the case of Citizens Utilities Company, which also offers two classes of stock, one that pays cash dividends and one that pays stock dividends. They find that the relative price of both classes varies over time and does not adjust to changes in relative taxation. However, these papers rely on tax differences between stock dividends and cash dividends, whereas our paper is based on a tax-neutral environment. 
Our paper is also related to the literature on dividend reinvestment plans ${ }^{2}$ (Scholes and Wolfson, 1989, Bierman, 1997, and Chiang, Frankfurter and Kosedag, 2005) and traditional stock dividends, which are offered to all shareholders on a pro-rata basis. Within this literature stream, Lakonishok and Lev (1987) find evidence showing that stock dividends provide a temporary substitute for cash dividends for firms that are unable to pay cash dividends, whereas other authors view stock dividends, similar to stock splits, as a way to keep the stock price within an acceptable trading range (He, $\mathrm{Li}$, Shi and Twite, 2012) or as a device to increase stock market liquidity (Copeland, 1979). Stock dividends are viewed as good news for shareholders (Grinblatt, Masulis and Titman, 1984), similar to optional stock dividends. However, they do not permit one to observe the decision of shareholders between stock and cash.

The remainder of the paper is organized as follows. In section 2, institutional settings are presented. Section 3 reviews various theories that have implications for the decision to pay optional stock dividends and develops testable hypotheses. Section 4 describes our data and explains the construction of various variables that are used in the study. Section 5 reports our findings concerning the reasons why firms use optional stock dividends. Section 6 provides evidence on the market reaction to stock dividend announcements and on the shareholder decision to choose stock rather than cash. Section 7 presents several robustness tests, and section 8 concludes.

\section{Institutional settings for the stock dividend option in France}

Since the law of 1983 (n83-1 - 3 January 1983), French firms have been allowed to pay dividends in either cash or stock. Firms have no tax motivation for optional stock dividends in France, as, since 1993, both stock and cash dividends are taxed similarly. The option has to be decided each year. At the annual general meeting approving the payment of a dividend, a separate resolution giving shareholders the option to payout dividends in either cash or newly created shares thus has to be approved. Shareholders have to define the new share issue price. According to the current legislation, this issue price must exceed $90 \%$ of the average closing

\footnotetext{
${ }^{2}$ DRIP plans are not standardized, and they may differ from one company to another. In general, they are only for the shareholders of record of a company, they permit investors to make voluntary cash payments directly into the plans, and some plans offer a discount. Shares sold through DRIPs are usually purchased in the secondary market. The costs of a DRIP are generally met by the contribution from participants in the form of a commission on the purchase of shares in the secondary market. Under an optional stock dividend scheme, the shares are issued and allotted directly by the company, without charge to investors.
} 
stock price over the 20 trading days prior to the general meeting, less the net amount of the dividend to be paid. In practice, firms tend to apply an exact $10 \%$ discount on the reference stock price. In 2009, more than $25 \%$ of the firms belonging to the CAC40 index (the major French index) used optional stock dividends.

The timing of the stock dividend option is voted on during the general meeting. Shareholders agree on the conversion period, starting from the ex-dividend date, during which they can individually opt for a dividend in cash or in stock for the total amount of their dividend and decide on the date of the dividend payment at which, when appropriate, new shares are to be issued and can be sold. Stock dividends can thus provide valuable options for shareholders, who can decide whether to invest given the available price information on the last date of the conversion period. ${ }^{3}$ However, shares are only available at the dividend payment date.

Shareholders exercising their option receive the nearest whole number of shares less than or equal to the product of the net dividend per share (DPS) and the number of shares held, divided by the new share issue price. ${ }^{4}$ Unlike traditional stock dividends, which are not taxable, stock dividends received as part of the optional mechanism follow the same taxation rules as cash dividends.

Thus, every shareholder can choose whether to receive a dividend in stock or in cash. Moreover, the stock dividend option only applies to dividends for the past fiscal year. However, the option can concern all or part of dividends. ${ }^{5}$ Despite being inherently similar to SEOs, stock dividends are not subject to SEO regulation. The stock dividend decision has to be made at the ordinary general meeting (a majority of 50\%), whereas SEOs are authorized at the extraordinary general meeting (supermajority of 2/3). Registration by AMF and information regulation for SEOs are not applicable to optional stock dividends. Finally, in contrast to the accounting of traditional stock dividends for which firms reduce their retained earnings account and increase their common stock account, the accounting of optional stock dividends acknowledges the distribution of a cash dividend and reinvests the amount. The accounting treats an optional stock dividend as a cash dividend plus a SEO.

To illustrate the optional stock dividend process, let us take the example of SANOFI in 2011. In the annual report, the firm managers expressed their willingness to offer shareholders

\footnotetext{
${ }^{3}$ Dammon and Spatt (1992) analyze the value of options and the optimal exercise policy in dividend reinvestment plans in the US, whereby most firms allow shareholders to make voluntary cash investments with a monthly, quarterly or annual maximum amount.

${ }^{4}$ The cash adjustment can be paid either by the firm or by the shareholder, who then receives a supplementary share.

${ }^{5}$ For example, Groupe Casino, one of the largest French retail firms, paid shareholders its 2011 dividend half in cash and half in shares.
} 
the stock dividend option to retain part of the 5.7 billion euro net profit realized in 2010. In the General Meeting of Shareholders (May 6, 2011), the payment of a DPS of $2.50 €$ was approved, and shareholders were offered the option to receive new shares instead of cash. The issue price was set at $49.60 €$, which represented the 20-day average stock price measured the day before the general meeting minus the net DPS, without a discount (the majority of other firms offer the maximum discount of 10\%). The conversion period was set from May 16, 2011 (the exdividend date) to June 3, 2011 (the share price on June 3 was 52.43€). Any shareholder who had not exercised the option at this date was entitled to receive the dividend in cash. The new shares, entitled to dividends on January 1, 2011, were listed on the Euronext Paris Stock Exchange on June 16, 2011-with an opening price of 51.68€. In all, 38,139,730 new shares were listed on the market, representing a $58 \%$ takeup and $2.9 \%$ of the capital. Not all shareholders exercised the conversion option, although the Sanofi stock price had remained above the issue price during the entire conversion period. Figure 1 presents the timeline of the optional stock dividend process for Sanofi. Figure 2, which was taken from the Sanofi website in 2014, shows that the firm presented its DPS history without mentioning that part of the dividend in 2010 was paid in stock.

\section{Hypotheses and predictions}

Paying optional stock dividends instead of cash dividends allows a firm to payout a dividend while preserving cash equal to the fraction of the total dividend that shareholders choose to receive as stock. The first question that arises is, why would firms offer shareholders an option for stock dividends to save cash rather than directly retaining earnings? If all shareholders choose stock dividends, the result is equivalent in terms of cash flow and stock equity balance to the firm retaining earnings. However, retaining earnings saves on taxes and transaction costs, specifically the administrative cost of running the stock dividend option and the transaction costs of reselling shares in the secondary market.

We first explore the monitoring hypothesis that firms prefer offering optional stock dividends rather than cutting dividends as a CEO monitoring device. Our second hypothesis posits that optional stock dividends provide an alternative way for firms to raise equity. According to our third hypothesis, optional stock dividends provide firms with a way to increase the proportion of long-term shareholders. 


\subsection{Optional stock dividends as a monitoring device}

Offering optional stock dividends to shareholders allows firms to avoid cutting dividends while saving cash. Cutting dividends may not be an acceptable option for a large fraction of firms, given the observed inflexibility in corporate dividend policies and the negative market reaction to the reduction or omission of dividends. Several models explaining dividend smoothing policies are based on information asymmetry (for example, Kumar, 1988 and Guttman, Kadan and Kandel, 2010). However, these models predict that the firms that face a higher degree of information asymmetry (younger, with growth options and high intangible assets) should be more likely to smooth dividends. Leary and Michaely (2011) find the opposite result, i.e., firms suffering from information asymmetry smooth dividends less than other firms.

Empirical results provide much more support for agency-based models. In these models, smoothed dividends are used to control the agency costs of free cash flow. According to Easterbrook (1984), paying high dividends forces firms to constantly stay in the market for capital, which allows current investors to monitor firm managers. By smoothing dividends, firms will continually expose themselves to the discipline of external financial markets and reduce agency costs. Easterbrook (1984) predicts that firms that simultaneously pay dividends and issue equity have higher stock value relative to other stocks. Dividends are useful as long as they force firms to go onto the market. As growth firms regularly raise capital, paying dividends would not help reduce agency costs. Dividends thus play a monitoring role for older and more mature firms, with less need for capital, by forcing them onto the market.

Institutional investors are particularly qualified as monitors. Allen, Bernardo, and Welch (2000) indicate that managers pay dividends to keep institutional investors with monitoring abilities among their shareholders. High-quality firms prefer institutions to hold their stock because these stockholders are better informed and have a relative advantage in detecting highquality firms. Low-quality firms do not have an incentive to mimic because they do not wish their true value to be revealed. In addition to reducing agency costs, other reasons for institutions to hold dividend-paying stocks are the associated tax status and the restrictions in certain charters (for example, the "prudent man" standard) that caused many institutions to avoid holding shares that did not pay dividends. Brav and Heaton (1998) indicate that dividendomitting firms underperformed only after the ERISA Act of 1974 took effect, which subjected private pension fund managers to a strict "prudent man" rule, and that many institutional investors have stopped holding stocks that omit dividends in the post-ERISA sample period.

The Allen, Bernardo, and Welch (2000) model supports dividend smoothing. Firms that pay dividends are unlikely to reduce the amount of their dividend because their clientele 
(institutions) are precisely the type of investors that will punish them for dividend cuts. Thus, they keep their dividends relatively smooth. Larkin, Leary, and Michaely (2014) empirically confirm that smoothing firms attract an institutional investor clientele.

According to the monitoring view, firms held by large shareholders are well monitored, and they do not require continuous exposure to the market for discipline. They can choose their dividend policy based on the primary cash needs of their shareholder and control considerations. Hege et al (2012) find that a large proportion of French family blockholders use leveraged pyramids and need cash dividends to service their debt. These firms should be less willing to offer optional stock dividends.

Optional stock dividends are therefore a device for firms that are suffering from a reduction in their earnings or their cash, but that are committed to paying a dividend to satisfy their investors' clientele. They allow firms to display a dividend payout while saving cash. Our prediction is that firms that use optional stock dividends are the most committed to paying dividends and those that benefit relatively more from direct monitoring by shareholders, i.e., mature firms, with a large fraction of their capital owned by institutional investors.

Our first hypothesis: Optional stock dividends play a role as a monitoring mechanism: firms are committed to paying the total dividend amount if all shareholders choose cash, and shareholders (and not managers) decide on the magnitude of the decrease in the cash payout.

\subsection{Optional stock dividend as an alternative method for issuing new equity}

Offering optional stock dividends resembles a small rights issue. If all shareholders take the dividend in stock, the firm is left with as much cash as if it had paid a cash dividend and then clawed it back from the same shareholders via a rights offering.

Firms using optional stock dividends could also pay cash dividends and independently raise equity before or after the dividend payout. However, the cost of an independent SEO may be larger than the cost of an optional stock dividend, at least during certain periods. Firms intending to issue new equity incur several direct and indirect costs. According to Eckbo et al (2007), expected flotation costs include the underwriter spread and out-of-pocket expenses (e.g., listing fees, fees to law firms and accountants, advertising, and management time devoted to the issue process), expected underpricing, the probability of offer cancellation multiplied by the expected cost of cancellation, and the negative stock price reaction to the announcement of the SEO. Many of these flotation costs substantially vary with market conditions. For example, the probability of cancellation and underpricing required to sell equity is higher during bear 
market periods. The market reaction to SEO announcements is also likely to be more negative during recession periods.

Issuing equity through optional stock dividends provides firms with a way to save a large part of these flotation costs. Even if the stock dividend option incurs some administrative costs, the costs of underwriting and the expected cost of cancellation, which are the largest part of the direct costs, are avoided. These costs vary according to period and country. Eckbo and Masulis (1992) find that the average direct cost of the firm commitment offering as a percent of the total issue proceeds is 6.09\%. In France, Ginglinger, Matsoukis and Riva (2013) report an average cost of $3.13 \%$, ranging from $2.55 \%$ for uninsured rights issues to $4.54 \%$ for public offerings. Further, for optional stock dividends, the potential negative market reaction to SEOs is avoided. Indeed, the Myers and Majluf (1984) adverse selection problem is reduced, as only current shareholders subscribe to new shares, even if some wealth transfer may occur between shareholders choosing stock dividends and those opting for the cash dividends.

Compared with SEOs, optional stock dividends can provide better or worse monitoring. On the one hand, Easterbook (1984) argues that new investors are better monitors than current shareholders, as they do not suffer under the collective choice disabilities. New investors will not buy new stock unless they can examine manager behavior and unless they can be compensated for the agency cost in the form of a lower subscription price. Underwriters of stock are also suppliers of the certification of firm value. In optional stock dividends, only current shareholders subscribe, and there is no underwriter: the monitoring effect is thus alleviated to a greater extent for optional stock dividends compared with independent SEOs. Therefore, optional stock dividends should only be used when SEOs are too expensive or unavailable.

On the other hand, optional stock dividends can be viewed as a way to raise capital with reduced agency costs. Shareholders authorize the use of optional stock dividends each year when they decide on dividends, whereas SEOs are authorized by general resolutions, for as long as 5 years. According to Holderness (2013), the absence of a shareholder decision just before each SEO may explain the negative market price reaction to SEOs, as there is no close control over the opportunity for the equity offering. Optional stock dividends provide firms with a way to raise capital over time, as such dividends lead to small SEOs each year, which reduces the information asymmetry between managers and shareholders through the regular public disclosure of information. Optional stock dividends can thus also be viewed as a type of stage 
financing. ${ }^{6}$ Further, each shareholder can choose to participate and receive stock instead of cash, which is comparable to a rights issue. In this view, optional stock dividends constitute the best monitoring device, as the capital increase will be limited to the amount that shareholders accept to take as stock.

The main cost associated to optional stock dividends is the discount offered to shareholders opting for stock dividends, the average of which is $8.3 \%$ (the legal maximum is $10 \%$ ). This discount is larger than the discount documented by Corwin (2003) for US SEOs (a 3\% discount for firm commitments in the 1990s). In France, the discount varies according to the flotation method. For example, Ginglinger et al (2013) find a 21.37\% discount for standby rights issues and $5.2 \%$ for public offerings. Discounts in rights offerings should be offset by the value of rights for shareholders. However, several studies document that shareholders who sell their rights suffer a substantial loss because the market for rights lacks liquidity (see, e.g., Massa, Vermaelen and $\mathrm{Xu}, 2013)$. Further, according to Corwin (2003), the discount increases with stock market volatility and with the increase in shares outstanding (which depends on the stock price for the given proceeds). In bear markets, volatility is high, and the stock price low, and both of these variables increase the discount of shares in traditional SEOs. During such periods, the discount in optional stock dividends may be lower than the discount in SEOs.

Our second hypothesis is that French firms will use optional stock dividends when they are unable to raise equity on the market at an acceptable cost. Firms will save flotation costs, avoid the usual negative announcement effect of SEOs, and allow the discount to be earned by the current shareholders opting for stock dividends.

\footnotetext{
${ }^{6}$ Stage financing is used by venture capital investors to enable them to abandon the entrepreneur's project if it fails to meet stage targets (e.g., Sahlman, 1990). Hertzel, Huson, and Parrino (2012) find that capital staging is employed by newly public firms to help control the overinvestment problem.
} 


\subsection{Ownership and wealth effect around optional stock dividends}

Firms may offer the option to pay stock dividends to reinforce the weight of long-term high valuation investors. In perfect capital markets, the investment horizon of investors does not matter, as a firm's stock price always equals its fundamental value and as arbitrage makes payout policy irrelevant for stock prices (Miller and Modigliani, 1961). However, the investment horizon matters if stocks are mispriced. Short-term investors may want to sell their shares before the mispricing is corrected, whereas long-term investors are able to wait until the stock price returns to its fundamental value. Several studies have indicated that investor horizons are important for financial decisions. For example, short-term investors have been shown to influence managers to reduce R\&D expenses (Bushee, 1998), to invest less (Derrien, Kecskes and Thesmar, 2013), and to prefer short-term projects (Graham, Harvey and Rajgopal, 2005). Gaspar, Massa, Matos, Patgiri, and Rehman (2012) find that firms held by short-term institutional investors have a higher propensity to repurchase shares, whereas firms pay dividends if their stock is held in large part by long-term investors who have less need to liquidate their investment. Optional stock dividends can thus be viewed as a mechanism that can help managers increase the percentage ownership of shareholders with high valuation of their firm (e.g., Ang and Kraizberg, 2004). Several examples support such a mechanism. In rights issues, rights are sold by low-value, short-term investors to long-term investors, leading to an increased proportion of the capital held by long-term investors. By using share repurchases, firms buy stock from short-term investors, increasing the percentage of capital held by long-term investors.

An additional interpretation of the optional stock dividend mechanism related to informed investors can be put forward. As Barclay and Smith (1988) and Brennan and Thakor (1990) suggest for the choice between repurchases and dividends, when cash dividends are paid, informed and uninformed investors receive a pro-rata amount. When the stock dividend option is available, better-informed shareholders may be able to take advantage of this information to opt for stock when it is worth more than the offer price and to opt for cash when it is worth less. ${ }^{7}$ Because of the fixed cost of collecting information, large shareholders will have a greater incentive than small shareholders to become informed. Hence, large shareholders should be more willing to choose stock dividends than small shareholders. The takeup of stock in optional

\footnotetext{
${ }^{7}$ However, as the proportion of stock dividend depends on shareholder demand, the wealth transfer from uninformed to informed shareholders is lower in the case of optional stock dividends than in the case of share repurchases.
} 
stock dividends should increase with the fraction of the capital owned by informed shareholders-whether blockholders or institutional investors. ${ }^{8}$

In addition to information asymmetry, as many firms that offer optional stock dividends provide stock at a discount, paying optional stock dividends may trigger wealth transfer between shareholders who prefer cash and those who are willing to subscribe to stock dividends, with the latter receiving the discount. The discount may also attract arbitrageurs. Some funds (e.g., index trackers) are unwilling to take the stock dividend option because their holdings would become larger than their investment guidelines permit. In such instances, stock can be lent out, and the borrower can choose the stock and sell the newly issued shares in the market. The proceeds from selling the shares are then used to pay the lender the cash dividend that they have forgone by lending the shares. The borrower makes a profit equal to the difference between the market value of the shares and the cash dividend, less the stock lending fee.

The market reaction to optional stock dividends should reflect the costs and benefits of the stock dividend option. On the one hand, informed trading and arbitrage strategies may be detrimental to current shareholders. On the other hand, offering optional stock dividend rather than cutting dividends or raising equity at a higher cost may represent a positive signal and may be beneficial to current shareholders. Further, one of the main benefits of optional stock dividends is that by giving shareholders the choice between cash and stock, optional stock dividends render shares more attractive to a wider clientele. We predict that the benefits are larger than the costs, leading to a positive market reaction.

Our third hypothesis can be declined as follows:

- Stock dividend takeup should increase with the proportion of informed and/or long-term shareholders, whether institutional investors or blockholders.

- Stock dividend takeup should also increase with the liquidity of the stock market, which favors arbitrage strategies.

- The market reaction to optional stock dividends should be positive.

\footnotetext{
${ }^{8}$ In perfect markets, the takeup should be either $0 \%$ or $100 \%$ depending on the stock price at the end of the option period.
} 


\section{Sample}

Our primary data source for dividend payments is the EUROFIDAI-OST database, which provides unique and detailed historical data on cash and stock dividends paid by French firms. We select firms listed on the CAC All Tradable index (former SBF 250) for the 2003-2012 period. ${ }^{9}$ The aggregate market value of these firms represents on average (median) 92.5\% (93.0\%) of the market capitalization of all public firms in France. Excluding hedge funds from our sample, ${ }^{10}$ we further obtain data on 2033 dividend payments initiated by 288 firms, including 168 cases of optional stock dividends. For each stock dividend payment option, the expiry date of the conversion option is manually extracted from either the Factiva database or firms official reports. We are able to identify all characteristic dates for 148 optional stocks dividends; however, the expiry date of the conversion option is not available for the remaining 36 observations. In addition, the Eurofidai database allows us to extract, for each observation, the total DPS, the reinvested DPS, and the issue price for new shares.

We complete our data by using vote results from firm shareholders' meetings. For every CAC All Tradable firm that uses the stock dividend option during a given year, we hand collect the corresponding vote results from shareholders' meetings and extract the percentage of votes in favor of the dividend payment and the proportion of votes in favor of the stock dividend option. We also collect the percentage of votes in favor of each resolution relative to a SEO, either a rights issue or a public offering.

Accounting and market data for the CAC All Tradable firms are extracted from the Thomson Reuters Datastream and Thomson Reuters Worldscope databases. We collect data for the fiscal years 2002 to 2011, corresponding to dividends initiated between 2003 and 2012. Because the Eurofidai database alone only allows us to sort between cash and stock dividends, we use Datastream data types to identify absences of dividends. In other words, we crossreference the two databases to identify listed firms that choose not to pay a dividend to their shareholders. In addition, we exclude from our sample all observations prior to a firm's first dividend payment. ${ }^{11}$ To prevent the effect of potential outliers, all variables are winsorized at the $5^{\text {th }}$ and $95^{\text {th }}$ percentiles. For the same fiscal period, we also extract ownership data from the Thomson One Banker database for the CAC All Tradable firms.

\footnotetext{
${ }^{9}$ Very few French firms use optional stock dividends outside the CAC All tradable index.

${ }^{10}$ Excluding all financial firms reduces the sample size too much. Keeping in mind their singularities, especially in terms of cash and leverage management, we thus decide to include them in our sample,and only exclude hedge funds.

${ }^{11}$ We identify a dividend initiation as the first strictly positive DPS reported in Datastream.
} 
Table 1, Panel A, reports the distribution of dividend payments over the 2003-2012 period. The table presents the total number of dividend payments, the number of observations without dividends, and the number and proportion of optional stock dividends. Optional stock dividends represent $8.26 \%$ of the observations over the entire period. Column 5 highlights a strong increase in optional stock dividends in 2009 and 2010, with more than 15\% of the dividend payments offered as optional stock dividends. Panel B reports the industry distribution of optional stock dividends.

Table 1, Panel C, details the characteristics of the stock dividend option. On average, if all shareholders chose to receive their dividend in stock for firms using the option, the capital would have increased by $4.2 \%$ (median 3.6\%). The average subscription rate (shareholder takeup) is $54.8 \%$ (median $63.1 \%$ ), which means that more than half of the shareholders choose stock rather than cash. Moreover, the actual mean capital increase is 2.3\% (median 2\%), and the mean discount at the end of the conversion period is $8.5 \%$ (median $8.1 \%$ ). The conversion period (from ex-dividend day to the last day when the choice for stock is possible) lasts on average 19.06 days (median 17 days), and the conversion to issue date (date when shareholders can sell their stock dividend) period lasts 11.56 days (median 11 days). At the issue date, the discount is still $8.5 \%$ on average (median $7.9 \%$ ).

We construct variables for firm profitability, size, cash holding, leverage, payout ratio, dividend yield, market-to-book ratio, stock return volatility, liquidity, and ownership by following the standard procedures in the literature. The variable construction and sources are described in the Appendix.

Table 2 reports the summary statistics and univariate comparison of various firm characteristics across the three categories of dividend payments: cash dividends, optional stock dividends, and dividend cuts (omissions or dividend cuts by more than 30\% for former dividend-paying firms). Firms offering optional stock dividends are larger, more frequently belong to the SBF120 index (largest French listed firms), and have a lower market-to-book ratio, less cash, and more debt than firms offering cash dividends only. The results in Table 2 also suggest that firms offering optional stock dividends have a higher dividend yield and a higher median payout ratio than firms offering cash dividends only. These firms are large, mature firms, which typically have an implicit contract to pay smoothed cash dividends. Institutional investors hold a larger fraction of the capital of these firms, and these firms are less frequently closely held: the largest shareholder holds $32.3 \%$ of the capital for optional stock dividend payers, whereas the largest shareholder holds 39.7\% of the capital for cash dividend payers. Further, optional stock dividends are more frequently used during recessions: the mean 
GDP variation during the year that the dividend is offered is $1.1 \%$ for cash dividends and $0.6 \%$ for optional stock dividends.

Table 2, in the last two columns, compares the characteristics of firms offering optional stock dividend with those of firms cutting dividends by at least 30\%. Optional stock dividend firms are larger on average: $60.1 \%$ of optional stock dividend firms belong to the SBF120 index, whereas $23.6 \%$ of firms omitting or cutting dividends belong to this index. Moreover, optional stock dividend firms hold less cash and have more debt than firms that cut dividends. Whereas net income variation is not significantly different between the cash dividend and optional stock dividend payers, firms cutting dividends significantly differ from the other firms by having a mean negative net income variation.

\section{Why do firms use optional stock dividends?}

In this section, we investigate whether the institutional variables and firm characteristics discussed in sections 2 and 3 influence the likelihood that firms use optional stock dividends. French firms can choose to pay an optional stock dividend rather than cutting dividends or paying a cash dividend. Each firm faces this discrete choice each year during the sample period. To examine the factors driving the payout choice, we first estimate a multinomial logit model. The choice set consists of a dividend cut, a cash dividend, and an optional stock dividend. We limit our sample to firms that paid at least one dividend over the period and exclude all observations prior to the initiation of dividends. Our sample thus comprises 274 unique firms, with a median number of 9 observations per firm. We assume that there is no natural ordering of the alternative payout channels. In a second step, we estimate several binomial logit models to investigate which factors determine the choice for cash dividend-paying firms between cutting or omitting dividends and paying optional stock dividends or between paying cash dividends and paying optional stock dividends. Because clustering effects could bias the statistical significance of the results owing to time series dependence (residuals for a given firm could be correlated over time), in estimating our regressions, we adjust the standard errors for clustering by firm.

Table 3 reports the multinomial logit regression results. Our first hypothesis posits that optional stock dividends are used by the firms that are the most committed to paying dividends. Further, the likelihood of offering the stock dividend option should increase for dividendpaying firms when they experience difficulties paying cash dividends. In Table 3, our results 
highlight that highly leveraged firms with low cash reserves and a higher past dividend yield have a higher probability of choosing optional stock dividends than cash dividends (which is the baseline category). By contrast, small firms with high leverage and negative income variation are more likely to cut dividends than to pay cash dividends.

In addition, the coefficient for institutional ownership is positive, suggesting that as institutions have a preference for dividends, optional stock dividends provide a mechanism to meet their expectations when a firm is short of cash. By contrast, the coefficient for the variable largest shareholder is significantly negative, suggesting that closely held firms offer optional stock dividends less frequently than other firms. Unlike in the US and the UK, where dispersed ownership predominates, in France, a considerable proportion of listed firms are closely held, reflecting ownership by multiple family branches that may have continued for decades. These large blockholders monitor the firm well; thus, these firms can choose a dividend policy without the need to use cash dividends as a monitoring device. Control considerations may deter these firms from offering optional stock dividends. Overall, these results suggest that firms that are committed to paying dividends are the most likely firms to use optional stock dividends when paying cash dividends becomes difficult.

According to our second hypothesis, firms will use optional stock dividends when they are unable to raise equity on the market at acceptable conditions. The results show that the recession dummy and the SEO discount variable are each significantly positive, suggesting that the likelihood that firms use optional stock dividends increases during economic downturns. However, because of multicollinearity, we cannot include both variables in a single regression.

Table 4 reports the binomial logit regression results. Panel A presents the regression results regarding how firms choose between dividend cuts and optional stock dividends. The sample comprises OSD paying firms and dividend cutters (omissions or dividend decreases by more than $30 \%$ for former dividend paying firms) and the dependent variable is a dummy that equals 1 in case of an OSD payment and 0 otherwise. The results show that net income variation and debt increase the likelihood that firms use optional stock dividends rather than cut dividends: firms offering optional stock dividends need equity to rebalance their capital structure but these firms are in a much better position than those that reduce their dividends in terms of their net income. Additionally, the coefficients for size and institutional ownership are positive, suggesting that large firms held by institutional investors- those that are the most committed to paying dividends - prefer to offer optional stock dividends than to cut dividends. By contrast, closely held firms prefer cutting dividends to offering optional stock dividends. These firms are reluctant to issue new shares for control considerations, and they do not require dividend 
smoothing as a monitoring device. Moreover, the coefficient for the Amihud illiquidity factor is negative, suggesting that more liquid firms prefer offering optional stock dividends to cutting dividends.

Panel B reports the regression results that examine how firms choose between cash dividends and optional stock dividends, and the results confirm the findings highlighted by the multinomial logit analysis. In particular, the coefficients for debt, recession, past dividend yield and institutional investors are positive, suggesting that leveraged firms that offer high dividend yield and are held by institutional investors are more likely to use optional stock dividends during recession periods. Further, closely held firms prefer cash dividends.

To provide further evidence on the characteristics that are important in firm's decision to use optional stock dividends, we perform several tests on matched samples based on size, year and industry characteristics (Table 5). We are able to obtain 286 (106) observations from 143 (53) unique pairs of matched firms for the choice between optional stock dividends and cash dividends (dividend cuts). We rerun our binomial logit regressions restricted to the matched samples and broadly confirm our previous results.

Overall, the evidence supports the view that firm characteristics have an important influence on the choice to offer optional stock dividends. Specifically, a stronger commitment to paying dividends when a recession occurs or when high leverage increases the need for equity is associated with a greater likelihood of offering optional stock dividends.

\section{Market reaction and shareholder choice}

\subsection{Announcement effects}

In this section, we examine equity market reactions to optional stock dividend, cash dividend, and dividend cut announcements. Our sample comprises all dividend announcements between 2003 and 2012, and we restrict our sample to events in which the announcement date is a nonmissing trading date. Daily abnormal returns are computed by using the market model for CAC All Tradable index, and market model parameters are estimated over 250 trading days ending 11 trading days before the dividend announcement. Table 6, Panel A, reports the CAR results on the announcement days. We observe that the stock price drops significantly at the announcement of a dividend cut. On average, the CARs in the $[-1,0]$ event window are $-0.68 \%$. By contrast, CARs are significantly positive at the announcement of an optional stock dividend, 
$+0.59 \%$, although they are not significantly different from CARs for traditional cash dividends $(+0.64 \%)$.

We then run multivariate regressions with CARs on the dividend announcement day as the dependent variable and report the results in Table 6, Panel B. Our variable of interest is the optional stock dividend dummy. We run regressions on two subsamples: (1) optional stock dividends and dividend cuts and (2) optional stock dividends and cash dividends, regardless of the DPS variation. On average, after we control for the variation of dividends and other firm characteristics, optional stock dividends experience a 1.5\% larger market reaction than dividend cuts (Table 6, Panel B, OLS regressions, models 1 to 3). The market reaction to optional stock dividends does not appear to be different from the market reaction to cash dividends (Table 6, Panel B, OLS regressions, models 7 to 9). Our models are estimated on the implicit assumption that the optional stock dividend dummy is exogenous. However, this dummy may not be exogenous, and the OLS estimates for the coefficients for the endogenous method dummies may therefore be inconsistent. Firms that may incur a more negative market reaction from cutting dividends are likely to prefer optional stock dividends. Therefore, we employ two-stage least-squares regressions to account for endogeneity. The first stage uses the independent variables presented in Table 4. The results of the second stage are reported in Table 6, Panel B, models 4 to 6 . Once we control for endogeneity issues, we find that the stock market reacts $4 \%$ more favorably to optional stock dividend announcements than to dividend cut announcements. The announcement effect does not differ between optional stock dividends and cash dividends.

Our evidence is consistent with our prediction that optional stock dividends are not bad news for shareholders: shareholders are willing to receive lower cash dividends if the firm is committed to paying the total amount of announced dividends. Further, the market reaction is positive, whereas the CARs at the announcement of a SEO are usually negative. The announcement of an optional stock dividend is therefore better news than the announcement of a dividend cut (even if the firms save on average half of the cash) and better news than the announcement of paying the total dividend and raising equity.

\subsection{Shareholder takeup}

Are shareholders willing to receive stock instead of dividends? This question has broad interest, as shareholders rarely have the choice between stock and cash dividends. In our setting, we can directly observe shareholders' willingness to receive stock dividends. First, on average, at the shareholders' general meeting, the percentage vote in favor of optional stock dividends is $98.48 \%$, which is slightly lower than but not significantly different from the percentage vote 
in favor of cash dividends (98.1\%). However, this percentage vote is significantly larger than the percentage vote in favor of SEOs with rights (94.7\%) and SEOs without rights (85.6\%).

We are able to observe shareholder takeup, which measures shareholders' willingness to receive stock instead of cash. Shares are proposed with a mean $8.5 \%$ discount (median 8.1\%). The mean shareholder takeup is 55.4\% (median 63.1\%). Table 7, Panel A, reports the values of takeup for several classes of discount. The takeup varies from $54.6 \%$ to $65.3 \%$ (with a median of $61.4 \%$ to $68.6 \%$ ) as long as the discount is positive at the end of the conversion period. Even when the discount is negative, the takeup is still positive, with a mean of 35.2\% (median 23.6\%). These findings suggest that shareholders do not choose stock dividends to obtain a pure arbitrage gain.

We run multivariate regressions with takeup as the dependent variable and report the results in Table 7, Panel B. The results show that the coefficient for discount is significantly positive, suggesting that shareholders choose stock rather than cash when the discount is high and when choosing stock is the most advantageous choice. The takeup increases with the fraction of capital held by institutional investors and by blockholders, confirming our hypothesis that the takeup should increase with the fraction of capital owned by informed and/or long-term shareholders. This result suggests that firms offer optional stock dividends when their stock is underpriced on the market. Further, institutional investors are the clientele for dividend-paying firms because of the monitoring role of dividends. Our results suggest that firms' commitment to paying dividends ensures the monitoring role of dividends, even if the dividend is not paid in cash. It is the firm's ability and willingness to pay nominal dividends that seem important, even if the final cash payout is reduced.

In section 5, we find that closely held firms are less likely to use optional stock dividends. However, once they have decided to use the optional stock dividend mechanism, blockholders subscribe to the new shares to avoid diluting their control and to use their positive information about the prospects of the firm. The takeup is largest the first time that the firm offers the option, and it decreases in the years that follow. Further, the takeup is larger when the market for the stock is more liquid and when the period from the general meeting to the ex-dividend day is longer, suggesting that shareholders have more time to decide and a better ability to trade on the stock. 


\subsection{Stock market reaction and abnormal volumes at the conversion and issue dates}

To further investigate market consequences of the optional stock dividend choice, we examine the stock market reaction and abnormal volumes at the end of the conversion period and around the effective payment date. Trading volumes are obtained from the Thomson Reuters Worldscope database, and daily abnormal volumes are computed by using an event study approach based on a mean model. We use the natural logarithm of volumes to compute both daily and mean trading volumes. To avoid any potential overlapping with OSD-related events (announcement, ex-dividend date), mean trading volumes are estimated over a 250-day period, ending 11 days before the announcement of an OSD payment. Daily abnormal volumes are computed as the difference between trading volumes on a given date, and the relevant mean trading volumes.

In Table 8, we report the average abnormal returns for the two-day event window, day -1 and 0 , where 0 is the end of the conversion period (the last day when shareholders can opt for stock dividends). The two-day average abnormal return at the end of conversion period is $0.571 \%$, and the two-day abnormal volume is 0.741 , both of which are statistically significant at the $1 \%$ level. At the effective payment of the dividend, when the new shares are listed on the market, the effect on abnormal returns for the period $(-1,0)$ is not significantly different from zero, although our results exhibit abnormal volumes (0.437 to 0.442 depending on the specification) for the same period. However, we find an abnormal return of -0.29 and an abnormal volume of 0.648 for the period $(1,2)$. These results suggest that some shareholders who opt for stock dividends at the end of the conversion period are simultaneously sellers of the stock on the market on the same date and that some of them sell their shares after they are listed. These findings suggest that even if optional stock dividends seem to be attractive to longterm shareholders, they also attract arbitrageurs who seek to capture the discount.

\section{Robustness}

In this section, we perform several additional robustness checks to ensure that our results are not sensitive to our specific variable definitions or empirical design.

In unreported analysis, we focus solely on nonfinancial firms and obtain results similar to those reported in the paper. We consider alternative measures of firm profitability and use different definitions of net income and EBITDA, and obtain similar results. We also use alternative measures of firm size, e.g., market value instead of total assets, and the results are 
unchanged. We then use several dummies to measure blockholders with more than $5 \%, 10 \%$, and $20 \%$ instead of the percentage of the capital held by the largest shareholders, and our results are again qualitatively unchanged. Further, when we implement different matching procedures to generate the results in Table 5, we obtain similar findings. We also consider thresholds of $40 \%$ and $50 \%$ for dividend cuts (instead of 30\%) in our dividend cut subsample and obtain similar results.

\section{Conclusions}

This paper presents an empirical analysis of the choice to offer optional stock dividends by French firms. We use a hand-collected dataset of firms offering optional stock dividends to investigate why firms choose this particular form of dividend and what the consequences are for shareholders. We find that firms that are the most committed to paying dividends are the most likely firms to use optional stock dividends when providing cash dividends becomes difficult: when recessions occur or when high leverage increases the need for equity. We further find that the abnormal stock returns upon the announcement of an optional stock dividend are positive: even if the cash payout decreases, optional stock dividends are good news for shareholders. Shareholders approve optional stock dividends, and a substantial portion of them subscribe to the new shares even if the discount is negative. Finally, the takeup increases with the fraction of the capital held by institutional investors and blockholders, who are informed and/or long-term shareholders, suggesting that firms offer optional stock dividends when their stock is underpriced on the market. 
Appendix: Variable definitions and data sources

\begin{tabular}{|c|c|}
\hline \multicolumn{2}{|c|}{ Economic conditions (Sources: INSEE, AMF) } \\
\hline GDP Growth & $\begin{array}{l}\text { Yearly change in the French GDP, as published by the INSEE (French } \\
\text { National Statistics Office) }\end{array}$ \\
\hline Recession & $\begin{array}{l}\text { Dummy variable that equals one if the economy is in recession according } \\
\text { to the INSEE definition (i.e. negative GDP Growth), and } 0 \text { otherwise. }\end{array}$ \\
\hline $\begin{array}{l}\text { Median Discount on } \\
\text { SEOs }\end{array}$ & $\begin{array}{l}\text { Yearly median discount on SEOs made by firms listed on compartiment } \\
\text { A of Eurolist by NYSE-Euronext (Source: registration notices, AMF) }\end{array}$ \\
\hline $\begin{array}{l}\text { Discount on SEOs } \\
\text { (dummy) }\end{array}$ & $\begin{array}{l}\text { Dummy variable that equals one if the median discount on SEOs in a } \\
\text { given year is in the top quartile of the distribution of all yearly median } \\
\text { discounts on SEOs }\end{array}$ \\
\hline \multicolumn{2}{|c|}{ Firm characteristics (source: Thomson Reuters Worldscope) } \\
\hline SBF 120 & $\begin{array}{l}\text { Dummy variable that equals one if a firm is in the SBF120 index and } \\
\text { zero otherwise }\end{array}$ \\
\hline Size & Logarithm of the book value of total assets (in thousand Euros) \\
\hline MtoB & Aggregate market value of the firm divided by aggregate book value \\
\hline Cash & Cash and cash equivalents divided by book value of total assets \\
\hline Debt & $\begin{array}{l}\text { Sum of short-term and long-term debt divided by book value of total } \\
\text { assets }\end{array}$ \\
\hline EBITDA/Assets & $\begin{array}{l}\text { Earnings Before Interests, Tax, Depreciation and Amoritization, divided } \\
\text { by the book value of total assets }\end{array}$ \\
\hline Net Income Variation & $\begin{array}{l}\text { Change in net income between two subsequent years, expressed in } \\
\text { percentage. }\end{array}$ \\
\hline $\begin{array}{l}\text { Amihud Illiquidity } \\
\text { Factor }\end{array}$ & $\begin{array}{l}\text { Amihud factor, computed for firm i as: } \\
\qquad\left(1 / D_{i}\right) \times \sum_{t=0}^{D_{i}}\left|r_{i t}\right| / E V o l_{i t} \\
\text { Where } r_{i t} \text { is firm's } i \text { stock return on date } t \text { EVol }{ }_{i t} \text { is the exchanged volume } \\
\text { - expressed in Euros - on date } \mathrm{t} \text {, and Di is the number of days with } \\
\text { available data during the fiscal year prior to a dividend payment. }\end{array}$ \\
\hline Short Term Illiquidity & $\begin{array}{l}\text { Amihud factor computed for the conversion period of an Optional Stock } \\
\text { Dividend (OSD) payment. Computed for OSD payers only. }\end{array}$ \\
\hline \multicolumn{2}{|c|}{ Dividend policy variables (source: Thomson Reuters Worldscope) } \\
\hline Dividend Yield & $\begin{array}{l}\text { Dividend per share (DPS) divided by the contemporaneous year-end } \\
\text { stock price }\end{array}$ \\
\hline Payout & $\begin{array}{l}\text { Dividend per share divided by earning per share for the } \\
\text { contemporaneous fiscal period }\end{array}$ \\
\hline OSD & $\begin{array}{l}\text { Dummy variable that equals one in the case of an Optional Stock } \\
\text { Dividend Payment, and zero otherwise. Used to identify OSD paying } \\
\text { firms. }\end{array}$ \\
\hline Dividend Cut & $\begin{array}{l}\text { Dummy variable that equals one if a firm decrease its DPS by more than } \\
30 \% \text {, including dividend omissions (100\% decrease), and zero } \\
\text { otherwise. Used to identify dividend cutters }\end{array}$ \\
\hline \multicolumn{2}{|c|}{ Ownership variables (Source: Thomson Reuters One Banker) } \\
\hline Institutio & $\begin{array}{l}\text { Number of shares held by institutional investors at the end of a given } \\
\text { fiscal year divided by the total number of traded shares }\end{array}$ \\
\hline
\end{tabular}




\begin{tabular}{|l|l|}
\hline Employee Ownership & $\begin{array}{l}\text { Number of shares held by a firm's employees at the end of a given fiscal } \\
\text { year divided by the total of number of traded shares }\end{array}$ \\
\hline Government Ownership & $\begin{array}{l}\text { Number of shares held by the French Government at the end of a given } \\
\text { fiscal year divided by the total number of traded shares }\end{array}$ \\
\hline Largest Shareholder & $\begin{array}{l}\text { Number of shares held by the largest shareholder at the end of a given } \\
\text { fiscal year divided by the total number of traded shares }\end{array}$ \\
\hline Optional stock dividend characteristics \\
\hline $\begin{array}{l}\text { \% Votes in Favor of } \\
\text { OSD }\end{array}$ & $\begin{array}{l}\text { Percentage of votes in favor of an Optional Stock Dividend (OSD), as } \\
\text { expressed during the shareholders' General Meeting }\end{array}$ \\
\hline $\begin{array}{l}\text { Conversion Period } \\
\text { (Days) }\end{array}$ & $\begin{array}{l}\text { Length of the conversion period, i.e. the number of days between the ex- } \\
\text { dividend date and the expiry date of the OSD conversion option }\end{array}$ \\
\hline $\begin{array}{l}\text { Conversion to Issue } \\
\text { Period (Days) }\end{array}$ & $\begin{array}{l}\text { Number of days between the end of the conversion period and the date } \\
\text { at which new shares are delivered to the shareholders who elected to } \\
\text { receive their dividend in shares (hereafter, the effective payment date) }\end{array}$ \\
\hline Takeup & Shareholders' subscription rate to an Optional Stock Dividend \\
\hline $\begin{array}{l}\text { Scrip Div \% Capital } \\
\text { (Maximum) }\end{array}$ & $\begin{array}{l}\text { Maximum (i.e. in the case of a 100\% takeup) number of shares issued } \\
\text { through an OSD payment, expressed as a percentage of a firm's total } \\
\text { number of shares }\end{array}$ \\
\hline $\begin{array}{l}\text { Scrip Div \% Capital } \\
\text { (Effective) }\end{array}$ & $\begin{array}{l}\text { Number of shares effectively issued through an OSD payment, expressed } \\
\text { as a percentage of a firm's total number of shares }\end{array}$ \\
\hline $\begin{array}{l}\text { Discount (End of } \\
\text { Conversion Period) }\end{array}$ & $\begin{array}{l}\text { Relative difference between the effective stock price at the end of the } \\
\text { conversion period and the issue price for shares issued through an OSD } \\
\text { payment }\end{array}$ \\
\hline Effective Discount & $\begin{array}{l}\text { Relative difference between the effective stock price at the effective } \\
\text { payment date and the issue price for shares issued through an OSD } \\
\text { payment }\end{array}$ \\
\hline
\end{tabular}




\section{References}

Aharony, J. and I. Swary, 1980, Quarterly dividend and earnings announcements and stockholders’ returns: an empirical analysis, Journal of Finance, 35, 1-12.

Allen, F., B. Antonio and I. Welch, 2000, A theory of dividends based on tax clienteles, Journal of Finance 55, 2499-2536

Ang J., D. Blackwell and W. Megginson, 1991, The effect of taxes on the relative valuation of dividends and capital gains: evidence from dual-class british investment trusts, Journal of Finance, 46, 383-399.

Ang J.. and E. Kraitzberg, 2004, An analysis of a strategy for management to separate and reward supportive shareholders, Journal of Corporate Finance, 10, 639-658.

Barclay, M. and C., Smith, 1988. Corporate payout policy: Cash dividends versus openmarket repurchases. Journal of Financial Economics 22, 61-82.

Bayless, M., and S. Chaplinsky, 1996, Is there a window of opportunity for seasoned equity issuance?, Journal of Finance 51, 253-278.

Bierman Jr., H., 1997. The dividend reinvestment plan puzzle. Applied Financial Economics, 7, 267-271.

Brav, A., J. Graham, C. Harvey, and R. Michaely, 2005, Payout policy in the 21st century, Journal of Financial Economics, 77, 483-527.

Brav, A., and J.B. Heaton, 1998, Did ERISA's prudent man rule change the pricing of dividend omitting firms?, Working paper, Duke University.

Brennan, M.. and A. Thakor, 1990, Shareholder Preferences and Dividend Policy, Journal of Finance, 45, 993-1019.

Bushee, B.J., 1998, The influence of institutional investors on myopic R\&D investment behavior, The Accounting Review , 73, 305-333.

Chiang K., G. Frankfurter and A. Kosedag, 2005, Exploratory analyses of dividend reinvestment plans and some comparisons, International Review of Financial Analysis 14, 570586.

Copeland, T.E., 1979. Liquidity Changes Following Stock Splits. Journal of Finance 34, 115-141.

Corwin, S. A. 2003, The Determinants of Underpricing for Seasoned Equity Offers. The Journal of Finance, 58, 2249-2279.

Derrien F., A. Kecskés and D. Thesmar, 2013, Investor Horizons and Corporate Policies, Journal of Financial and Quantitative Analysis, 48, 1755-1780 
Eckbo, E., and R. Masulis, 1992, Adverse selection and the rights offer paradox, Journal of Financial Economics 32, 293-322

Eckbo E., R. Masulis and O. Norli, 2007, Security offerings, in Espen Eckbo (ed.), Handbook of Corporate Finance: Empirical Corporate Finance, Volume 1. NorthHolland/Elsevier.

Easterbrook FH. 1984. Two agency-cost explanations of dividends. American Economic Review, 74, 650-59.

Gaspar, J.-M., M. Massa, P. Matos, R. Patgiri, and Z. Rehman. 2013, Payout policy choices and shareholder investment horizons. Review of Finance, 17, 261-320.

Ginglinger E., L. Koenig, and F. Riva, 2013, Seasoned equity offerings: Stock market liquidity and the rights offer paradox, Journal of Business, Finance and Accounting, 40, 215238

Graham, J. R., C. R. Harvey, and S. Rajgopal. 2005, The economic implications of corporate financial reporting. Journal of Accounting and Economics, 40, 3-73.

Grinblatt, M. S., Masulis, R.W. and S. Titman, 1984. The valuation effects of stock splitsand stock dividends. Journal of Financial Economics 13, 461-490.

Guttman, I., O. Kadan, and E. Kandel. 2010. Dividend stickiness and strategic pooling. Review of Financial Studies 23, 4455-95

He X., M. Li, J. Shi and G. Twite, 2012, Stock versus cash dividends: signaling or catering, working paper.

Hege U., A. de Jong, D. DeJong and G. Mertens, 2012, Blockholders and leverage: when debt leads to higher dividends, Working Paper, HEC Paris

Hertzel M., M. Huson and R. Parrino, 2012, Public market staging: The timing of capital infusions in newly public firms, Journal of Financial Economics 106, 72-90.

Holderness C., 2013, Seasoned equity offerings and agency costs: the telling story of shareholder approval around the world, Working paper.

Hubbard J. and R. Michaely, 1997, Do investors ignore dividend taxation? A reexamination of the citizens utilities case, Journal of Financial and Quantitative analysis, 32, 1, 117-135

Jacquillat B., 1992, The dual method of corporate profits distribution in France: an empirical and clinical study 1983-1991, Working paper, The Hoover Institution, Stanford University

Jagannathan, M., C. P. Stephens, and M. S. Weisbach, 1999, Financial flexibility and the choice between dividends and stock repurchases, Journal of Financial Economics 57, 355-384. 
Jacquemet Marie-Jeanne C., 1998, Le paiement du dividende en actions : motivation, signal et evaluation, Phd thesis, Université de Strasbourg

Kumar P. 1988. Shareholder-manager conflict and the information content of dividends. Review of Financial Studies, 1, 111-136

Lakonishock, J. and B. Lev, 1987. Stock splits and stock dividends: why, who and when. Journal of Finance 42, 913-932.

Larkin Y., M. Leary and R. Michaely, 2014, Do investors value dividend smoothing stocks differently? Working paper, Cornell University.

Lasfer A., 1997, On the motivation for paying scrip dividends, Financial Management, 26, 62-80.

Leary, M.T. and R. Michaely, 2011, Determinants of dividend smoothing: empirical evidence, Review of Financial Studies 24, 3197-3249.

Lintner, J., 1956, Distribution of incomes of corporations among dividends, retained earnings, and taxes, American Economic Review, 46, 97-113.

Massa M., T. Vermaelen, and M. Xu, 2013, Rights offering, trading and regulation: a global perspective. Working paper.

Miller, M. and F. Modigliani, 1961, Dividend policy, growth and the valuation of shares, Journal of Business 34, 1031-1051.

Myers S.C., 1993, Still searching for optimal capital structure, Journal of applied corporate finance, 6, 4-14

Myers SC and NS Majluf,1984, Corporate financing and investment decisions when firms have information that investors do not have. Journal of Financial Economics, 13, 187-221.

Pettit, R. R., 1972, Dividend announcements, security performance, and capital market efficiency, Journal of Finance, 27 (5), 993-1007.

Sahlman, W., 1990. The structure and governance of venture-capital organizations. Journal of Financial Economics 27, 473-521.

Scholes, M. S., and Wolfson, M.A. 1989. Decentralized investment banking: The case of discount dividend-reinvestment and stock-purchase plans. Journal of Financial Economics, 17, $7-35$. 


\section{Table 1: Optional Stocks Dividends - Summary Statistics}

\section{Panel A: Yearly Distribution of Dividend Payments}

The sample consists of 288 listed (CAC All Tradable) French firms for the period 2003-2012. Column 1 presents the number of available observations in each year. Column 2 presents the number of dividend payments - including optional stock dividends (hereafter OSD) - in each year. Column 3 presents the number of dividend omissions in each year. Columns 4 and 5 present the number of OSD, and OSD as percentage of the total number of dividend payments in each year.

\begin{tabular}{lccccc}
\hline Year & Obs. & $\begin{array}{c}\text { Dividend } \\
\text { Payments (All) }\end{array}$ & No Dividend & OSD & \% OSD \\
\hline 2003 & 245 & 176 & 69 & 10 & $5.68 \%$ \\
2004 & 253 & 178 & 75 & 10 & $5.62 \%$ \\
2005 & 260 & 191 & 69 & 11 & $5.76 \%$ \\
2006 & 268 & 204 & 64 & 8 & $3.92 \%$ \\
2007 & 278 & 219 & 59 & 11 & $5.02 \%$ \\
2008 & 279 & 231 & 48 & 12 & $5.19 \%$ \\
2009 & 279 & 201 & 78 & 32 & $15.92 \%$ \\
2010 & 282 & 198 & 84 & 31 & $15.66 \%$ \\
2011 & 285 & 219 & 66 & 25 & $11.42 \%$ \\
2012 & 283 & 216 & 67 & 18 & $8.33 \%$ \\
& & & & & \\
Total & 2712 & 2033 & 679 & 168 & $8.26 \%$ \\
\hline
\end{tabular}


Table 1: Optional Stocks Dividends - Summary Statistics (cont'd)

\section{Panel B: Industry Distribution of Dividend Payments}

The sample consists of 288 listed (CAC All Tradable) French firms for the period 2003-2012. Industries are identified using the 1-digit SIC Code classification. Column 1 reports the total number of dividend payments in each industry, including optional stock dividends. Column 2 reports the number of dividends payments in each industry as a percentage of the total number of dividend payments. Column 3 reports the total number of OSD in each industry. Column 4 reports the number of OSD in each industry as a percentage of the total number of dividend payments in each industry.

\begin{tabular}{|c|c|c|c|c|c|}
\hline \multirow[b]{2}{*}{$\begin{array}{l}\text { SIC } \\
\text { Code }\end{array}$} & \multirow[b]{2}{*}{ Industry } & \multicolumn{2}{|c|}{ Cash Dividends } & \multicolumn{2}{|c|}{ Optional Stock Dividends } \\
\hline & & Observations & \% Total Sample & Observations & \% Total Sample \\
\hline 0 & Agriculture, Forestry and Fishing & 15 & $0.74 \%$ & 0 & $0.00 \%$ \\
\hline 1 & Mining & 119 & $5.85 \%$ & 6 & $5.04 \%$ \\
\hline 2 & Manufacturing & 297 & $14.61 \%$ & 14 & $4.71 \%$ \\
\hline 3 & Manufacturing & 489 & $24.05 \%$ & 39 & $7.98 \%$ \\
\hline 4 & $\begin{array}{l}\text { Transportation, Communication, } \\
\text { Electric, Gas and Sanitary Services }\end{array}$ & 215 & $10.58 \%$ & 14 & $6.51 \%$ \\
\hline 5 & Wholesale and Retail Trade & 170 & $8.36 \%$ & 19 & $11.18 \%$ \\
\hline 6 & Finance, Insurance and Real Estate & 281 & $13.82 \%$ & 60 & $21.35 \%$ \\
\hline 7 & Services & 359 & $17.66 \%$ & 16 & $4.46 \%$ \\
\hline 8 & Services & 78 & $3.84 \%$ & 0 & $0.00 \%$ \\
\hline 9 & Public Administration & 10 & $0.49 \%$ & 0 & $0.00 \%$ \\
\hline Total & & 2033 & $100.00 \%$ & 168 & $8.26 \%$ \\
\hline
\end{tabular}


Table 1: Optional Stocks Dividends - Summary Statistics (cont'd)

Panel C: Optional Stock Dividends - Characteristics

This table presents summary statistics for the key characteristics of optional stock dividends (hereafter OSD) payments. The sample consists of 168 OSD paid by French listed firms during the period 2003-2012. Definitions of all variables are reported in the Appendix.

\begin{tabular}{lcccc}
\hline Variables & Observations & Mean & Median & Std Dev \\
\hline \% Votes in Favor of OSD & 168 & 98.475 & 99.5 & 0.027 \\
Conversion Period (Days) & 145 & 19.062 & 17 & 9.187 \\
Conversion to Issue Period (Days) & 145 & 11.559 & 11 & 4.136 \\
Takeup & 160 & 0.554 & 0.631 & 0.254 \\
Scrip Div \% Capital (Theoretical) & 150 & 0.042 & 0.035 & 0.034 \\
Scrip Div \% Capital (Effective) & 142 & 0.023 & 0.019 & 0.020 \\
Discount (End of Conversion Period) & 145 & 0.085 & 0.081 & 0.104 \\
Effective Discount & 165 & 0.085 & 0.079 & 0.117 \\
\hline
\end{tabular}




\section{Table 2: Dividend Policy - Univariate Comparisons}

This table presents the summary statistics and univariate comparisons of various firm characteristics across three categories of dividend payments: (i) cash dividends (excluding dividend initiations), (ii) optional stock dividends (hereafter OSD) and (iii) dividend cuts (omissions or dividend decreases by more than 30\% for former dividend paying firms). Definitions of all variables are reported in the Appendix. ***, ** and * indicate significance of $\mathrm{t}$-statistics (chi-squared) for the test of difference in means (medians) between two subsamples, at the $1 \%, 5 \%$ and $10 \%$ levels, respectively.

(Continued on next page) 


\begin{tabular}{|c|c|c|c|c|c|c|c|c|}
\hline \multirow[b]{2}{*}{ Variables } & \multicolumn{2}{|c|}{ Cash Dividends } & \multicolumn{2}{|r|}{ OSD } & \multicolumn{2}{|c|}{ Dividend Cuts } & \multicolumn{2}{|c|}{ T-stats } \\
\hline & $\begin{array}{l}\text { Obs } \\
\end{array}$ & $\begin{array}{c}\text { Mean } \\
\text { [Median] }\end{array}$ & Obs & $\begin{array}{c}\text { Mean } \\
\text { [Median] }\end{array}$ & Obs & $\begin{array}{c}\text { Mean } \\
\text { [Median] }\end{array}$ & $\begin{array}{c}\text { Cash vs } \\
\text { OSD }\end{array}$ & $\begin{array}{c}\text { Cuts vs } \\
\text { OSD }\end{array}$ \\
\hline GDP Growth & 1865 & $\begin{array}{c}0.011 \\
{[0.018]}\end{array}$ & 168 & $\begin{array}{c}0.006 \\
{[0.017]}\end{array}$ & 208 & $\begin{array}{c}0.001 \\
{[0]}\end{array}$ & $\begin{array}{c}2.926 * * * \\
{[8.927 * * *]}\end{array}$ & $\begin{array}{c}-2.378^{* *} \\
{[1.233]}\end{array}$ \\
\hline Recession & 1865 & $\begin{array}{c}0.208 \\
{[0]}\end{array}$ & 168 & $\begin{array}{c}0.262 \\
{[0]}\end{array}$ & 208 & $\begin{array}{c}0.394 \\
{[0]}\end{array}$ & $\begin{array}{l}-1.526 \\
{[2.672]}\end{array}$ & $\begin{array}{c}2.752^{* * *} \\
{[7.304 * * *]}\end{array}$ \\
\hline SBF 120 & 1865 & $\begin{array}{c}0.457 \\
{[0]}\end{array}$ & 168 & $\begin{array}{c}0.601 \\
{[1]}\end{array}$ & 208 & $\begin{array}{c}0.236 \\
{[0]}\end{array}$ & $\begin{array}{c}-3.645^{* * *} \\
{\left[12.896^{* * *}\right]}\end{array}$ & $\begin{array}{c}-7.614^{* * *} \\
{[51.809 * * *]}\end{array}$ \\
\hline Median Discount on SEOs & 1865 & $\begin{array}{c}0.312 \\
{[0.284]}\end{array}$ & 168 & $\begin{array}{c}0.411 \\
{[0.331]}\end{array}$ & 208 & $\begin{array}{c}0.457 \\
{[0.316]}\end{array}$ & $\begin{array}{c}-2.494 * * \\
{[9.890 * * *]}\end{array}$ & $\begin{array}{c}0.849 \\
{[0.800]}\end{array}$ \\
\hline \multicolumn{9}{|l|}{ Financials } \\
\hline Size & 1850 & $\begin{array}{c}13.871 \\
{[13.579]}\end{array}$ & 168 & $\begin{array}{c}14.699 \\
{[14.282]}\end{array}$ & 207 & $\begin{array}{c}12.927 \\
{[12.614]}\end{array}$ & $\begin{array}{l}-3.712 * * * \\
{[12.57 * * *]}\end{array}$ & $\begin{array}{c}-6.49 * * * \\
{\left[36.838^{* * *}\right]}\end{array}$ \\
\hline MtoB & 1865 & $\begin{array}{l}1.987 \\
{[1.64]}\end{array}$ & 168 & $\begin{array}{l}1.447 \\
{[1.23]}\end{array}$ & 208 & $\begin{array}{l}1.522 \\
{[1.14]}\end{array}$ & $\begin{array}{c}7.558^{* * *} \\
{[21.149 * * *]}\end{array}$ & $\begin{array}{c}0.698 \\
{[2.046]}\end{array}$ \\
\hline Cash & 1850 & $\begin{array}{c}0.135 \\
{[0.104]}\end{array}$ & 168 & $\begin{array}{c}0.092 \\
{[0.077]}\end{array}$ & 207 & $\begin{array}{l}0.127 \\
{[0.1]}\end{array}$ & $\begin{array}{c}6.484^{* * *} \\
{\left[17.557^{* * *}\right]}\end{array}$ & $\begin{array}{l}3.282^{* * *} \\
{\left[5.982^{* *}\right]}\end{array}$ \\
\hline Debt & 1865 & $\begin{array}{c}0.322 \\
{[0.359]}\end{array}$ & 168 & $\begin{array}{c}0.454 \\
{[0.429]}\end{array}$ & 208 & $\begin{array}{c}0.259 \\
{[0.374]}\end{array}$ & $\begin{array}{c}-5.723^{* * *} \\
{\left[20.408^{* * *}\right]}\end{array}$ & $\begin{array}{c}-2.142 * * \\
{[4.304 * *]}\end{array}$ \\
\hline Net Income Variation & 1742 & $\begin{array}{c}0.224 \\
{[0.123]}\end{array}$ & 155 & $\begin{array}{c}0.188 \\
{[0.099]}\end{array}$ & 176 & $\begin{array}{l}-0.404 \\
{[-.468]}\end{array}$ & $\begin{array}{l}0.494 \\
{[.17]}\end{array}$ & $\begin{array}{c}-6.095^{* * *} \\
{\left[42.91^{* * *}\right]}\end{array}$ \\
\hline Amihud illiquidity Factor & 1841 & $\begin{array}{c}1.692 \\
{[0.045]}\end{array}$ & 164 & $\begin{array}{l}1.646 \\
{[0.01]}\end{array}$ & 207 & $\begin{array}{c}3.524 \\
{[0.314]}\end{array}$ & $\begin{array}{c}0.072 \\
{\left[6.765^{* *}\right]}\end{array}$ & $\begin{array}{c}2.215^{* *} \\
{\left[29.051^{* * *}\right]}\end{array}$ \\
\hline \multicolumn{9}{|l|}{ Dividend Policy } \\
\hline Dividend Yield & 1859 & $\begin{array}{c}0.034 \\
{[0.027]}\end{array}$ & 164 & $\begin{array}{c}0.046 \\
{[0.039]}\end{array}$ & 208 & $\begin{array}{c}0.019 \\
{[0.012]}\end{array}$ & $\begin{array}{c}-2.9 * * * \\
{[24.342 * * *]}\end{array}$ & $\begin{array}{l}-6.149^{* * *} \\
{\left[84.45^{* * *}\right]}\end{array}$ \\
\hline Payout Ratio & 1774 & $\begin{array}{c}0.643 \\
{[0.373]}\end{array}$ & 145 & $\begin{array}{l}0.674 \\
{[0.5]}\end{array}$ & 143 & $\begin{array}{c}0.554 \\
{[0.247]}\end{array}$ & $\begin{array}{c}-0.341 \\
{\left[26.036^{* * *}\right]}\end{array}$ & $\begin{array}{c}-0.893 \\
{[33.349 * * *]}\end{array}$ \\
\hline \multicolumn{9}{|l|}{ Ownership Structure } \\
\hline Institutional Ownership & 1728 & $\begin{array}{c}0.399 \\
{[0.376]}\end{array}$ & 141 & $\begin{array}{c}0.445 \\
{[0.468]}\end{array}$ & 189 & $\begin{array}{c}0.354 \\
{[0.262]}\end{array}$ & $\begin{array}{c}-2.219 * * \\
{[8.392 * * *]}\end{array}$ & $\begin{array}{c}.404^{* * *} \\
{\left[13.485^{* * *}\right]}\end{array}$ \\
\hline Employee Ownership & 1824 & $\begin{array}{c}0.013 \\
{[0]}\end{array}$ & 158 & $\begin{array}{c}0.022 \\
{[0]}\end{array}$ & 200 & $\begin{array}{c}0.01 \\
{[0]}\end{array}$ & $\begin{array}{c}-2.599 * * \\
{[.381]}\end{array}$ & $\begin{array}{c}.404^{* * *} \\
{[5.706 * *]}\end{array}$ \\
\hline Governement Ownership & 1821 & $\begin{array}{c}0.013 \\
{[0]}\end{array}$ & 157 & $\begin{array}{c}0.011 \\
{[0]}\end{array}$ & 200 & $\begin{array}{c}0.006 \\
{[0]}\end{array}$ & $\begin{array}{l}0.264 \\
{[.513]}\end{array}$ & $\begin{array}{l}0.404 \\
{[.167]}\end{array}$ \\
\hline Largest Shareholder & 1839 & $\begin{array}{c}0.397 \\
{[0.395]}\end{array}$ & 163 & $\begin{array}{l}0.323 \\
{[0.27]}\end{array}$ & 201 & $\begin{array}{c}0.416 \\
{[0.385]}\end{array}$ & $\begin{array}{l}3.636^{* * *} \\
{[5.554 * *]}\end{array}$ & $\begin{array}{l}.404^{* * *} \\
{[1.878]}\end{array}$ \\
\hline
\end{tabular}




\section{Table 3: Dividend policy choice model}

This table presents a multinomial logit analysis of the choice of dividend policy. The sample consists of 288 French firms belonging to the CAC All Tradable index during the period 2003-2012 (2148 firm-year observations). In columns (1) to (5), the dependent variable is equal to: 0 in the case of a dividend omission (No Div), 1 in the case of cash dividend payment, regardless of the variation of the DPS and 2 in the case of an Optional Stock Dividend $(O S D)$. Column (6) presents the results of a slightly different specification, where the dependent variable equals: 0 in the case of a dividend omission or a cash dividend payment with a decrease of the DPS larger than 30\% (Div Cut), 1 in the case of a dividend payment with a non-negative change of the DPS and 2 in the case of an OSD. In all specifications, the baseline for the multinomial logistic regression is at the dependent variable being equal to 1 . Dividend initiations are excluded. Definitions of all variables are reported in the Appendix. Robust standard errors clustered by firm are used. The corresponding p-values are reported between brackets. ***, ** and * indicate significance at the $1 \%, 5 \%$ and $10 \%$ levels, respectively.

(Continued on next page) 
Table 3: Dividend policy choice model (cont'd)

\begin{tabular}{|c|c|c|c|c|c|c|c|c|c|c|c|c|}
\hline \multirow[b]{2}{*}{ Variables } & \multicolumn{2}{|c|}{ (1) } & \multicolumn{2}{|c|}{$(2)$} & \multicolumn{2}{|c|}{ (3) } & \multicolumn{2}{|c|}{ (4) } & \multicolumn{2}{|c|}{ (5) } & \multicolumn{2}{|c|}{ (6) } \\
\hline & No Div & OSD & No Div & OSD & No Div & OSD & No Div & OSD & No Div & OSD & Div Cut & OSD \\
\hline \multirow[t]{2}{*}{ Cash } & -1.012 & $-2.891 * *$ & -0.752 & $-2.480 * *$ & -0.767 & $-2.621^{* *}$ & -0.274 & -2.064 & -0.676 & -1.862 & -0.160 & $-2.748 * *$ \\
\hline & $(0.439)$ & $(0.025)$ & $(0.555)$ & $(0.032)$ & $(0.546)$ & $(0.026)$ & $(0.816)$ & $(0.104)$ & $(0.568)$ & $(0.143)$ & $(0.863)$ & $(0.047)$ \\
\hline \multirow[t]{2}{*}{ Debt } & $3.922 * * *$ & $1.673^{* * *}$ & $3.701^{* * *}$ & $1.440 * *$ & $3.714^{* * *}$ & $1.488 * * *$ & $4.434^{* * *}$ & $2.217 * * *$ & $4.019 * * *$ & $2.178^{* * *}$ & $3.461^{* * *}$ & $2.360 * * *$ \\
\hline & $(0.000)$ & $(0.005)$ & $(0.000)$ & $(0.012)$ & $(0.000)$ & (0.009) & $(0.000)$ & $(0.001)$ & $(0.000)$ & $(0.001)$ & $(0.000)$ & $(0.000)$ \\
\hline \multirow[t]{2}{*}{ Size } & $-0.411^{* * *}$ & -0.028 & $-0.392 * * *$ & -0.017 & $-0.392 * * *$ & -0.018 & $-0.414 * * *$ & $-0.156^{* *}$ & $-0.394 * * *$ & $-0.150 * *$ & $-0.359 * * *$ & $-0.226 * * *$ \\
\hline & $(0.000)$ & $(0.623)$ & $(0.000)$ & $(0.761)$ & $(0.000)$ & $(0.748)$ & $(0.000)$ & $(0.024)$ & $(0.000)$ & $(0.036)$ & $(0.000)$ & $(0.002)$ \\
\hline \multirow[t]{2}{*}{ MtoB } & -0.182 & -0.115 & $-0.235^{* *}$ & -0.188 & $-0.227 *$ & -0.161 & -0.169 & -0.115 & $-0.212^{*}$ & -0.105 & $-0.256^{* *}$ & -0.127 \\
\hline & $(0.132)$ & $(0.446)$ & $(0.036)$ & (0.169) & $(0.052)$ & $(0.250)$ & (0.189) & $(0.484)$ & $(0.079)$ & $(0.526)$ & $(0.015)$ & (0.438) \\
\hline \multirow[t]{2}{*}{ Net Income Variation } & $-0.248 * * *$ & 0.097 & $-0.279 * * *$ & 0.072 & $-0.285^{* * *}$ & 0.016 & $-0.231 * *$ & 0.119 & $-0.353^{* * *}$ & 0.157 & $-0.453^{* * *}$ & 0.033 \\
\hline & $(0.006)$ & $(0.355)$ & $(0.001)$ & $(0.506)$ & $(0.001)$ & $(0.885)$ & $(0.018)$ & $(0.325)$ & $(0.000)$ & $(0.230)$ & $(0.000)$ & $(0.808)$ \\
\hline \multirow[t]{2}{*}{ GDP Growth } & & & -2.975 & $-14.665 * * *$ & & & & & & & & \\
\hline & & & $(0.389)$ & $(0.003)$ & & & & & & & & \\
\hline \multirow[t]{2}{*}{ Median discount on SEOs } & & & & & 0.778 & $3.136 * *$ & & & & & & \\
\hline & & & & & $(0.374)$ & $(0.010)$ & & & & & & \\
\hline \multirow[t]{2}{*}{ Recession } & & & & & & & $0.846^{* * *}$ & $1.770^{* * *}$ & $0.840 * * *$ & $1.678^{* * *}$ & $0.840^{* * *}$ & $2.134 * * *$ \\
\hline & & & & & & & $(0.002)$ & $(0.000)$ & $(0.003)$ & $(0.001)$ & $(0.001)$ & $(0.000)$ \\
\hline \multirow[t]{2}{*}{ Institutional Ownership } & & & & & & & 0.329 & $1.196^{*}$ & 0.273 & 1.141 & 0.144 & $1.184^{*}$ \\
\hline & & & & & & & $(0.515)$ & $(0.083)$ & $(0.569)$ & $(0.101)$ & $(0.715)$ & $(0.089)$ \\
\hline \multirow[t]{2}{*}{ Largest Shareholder } & & & & & & & $-1.132 *$ & $-2.734 * * *$ & $-1.241 * *$ & $-2.537 * * *$ & -0.785 & $-3.039 * * *$ \\
\hline & & & & & & & $(0.071)$ & $(0.001)$ & $(0.033)$ & $(0.002)$ & $(0.128)$ & $(0.000)$ \\
\hline \multirow[t]{2}{*}{ Past Dividend Yield } & & & & & & & & & $-27.816^{* *}$ & $4.463 * * *$ & & \\
\hline & & & & & & & & & $(0.015)$ & $(0.006)$ & & \\
\hline \multirow[t]{2}{*}{ Constant } & $2.863 * * *$ & $-3.387 * * *$ & $3.246 * * *$ & $-2.504 * * *$ & $2.976 * * *$ & $-3.582 * * *$ & $2.859 * * *$ & -1.651 & $3.949 * * *$ & $-2.235 *$ & $3.453^{* * *}$ & -0.816 \\
\hline & $(0.003)$ & $(0.001)$ & $(0.001)$ & $(0.002)$ & $(0.004)$ & $(0.001)$ & $(0.004)$ & $(0.138)$ & $(0.000)$ & $(0.061)$ & $(0.000)$ & $(0.508)$ \\
\hline Observations & \multicolumn{2}{|c|}{2,148} & \multicolumn{2}{|c|}{2,148} & \multicolumn{2}{|c|}{2,148} & \multicolumn{2}{|c|}{1,985} & \multicolumn{2}{|c|}{1,975} & \multicolumn{2}{|c|}{1,817} \\
\hline Year dummies & \multicolumn{2}{|c|}{ Yes } & \multicolumn{2}{|c|}{ No } & \multicolumn{2}{|c|}{ No } & $\mathrm{Y}$ & es & $\mathrm{Y}$ & es & $\mathrm{Y}$ & es \\
\hline Industry dummies & $\mathrm{Y}$ & es & & es & $\mathrm{Y}$ & es & $\mathrm{Y}$ & es & $\mathrm{Y}$ & es & $\mathrm{Y}$ & es \\
\hline Pseudo R² & 0.1 & 66 & & 142 & 0.1 & 41 & 0.1 & 89 & 0.2 & 20 & 0.1 & 87 \\
\hline
\end{tabular}


Table 4: Logistic Regressions on the Likelihood of Firms Paying Optional Stock Dividends This table reports the logistic regression results estimating the probability of paying an Optional Stock Dividend (hereafter OSD). The overall sample comprises French listed firms (CAC All Tradable) during the period 2003-2012. In Panel A, the sample comprises 251 firm-year observations (OSD paying firms and dividend cutters - omissions or dividend decreases by more than $30 \%$ for former dividend paying firms) and the dependent variable is a dummy that equals 1 in case of an OSD payment and 0 otherwise. In Panel B, the sample comprises 1709 firm-year observations (dividend paying firms) and the dependent variable is a dummy that equals 1 in case of an OSD payment and 0 otherwise. Definitions of all variables are reported in the Appendix. Robust standard errors clustered by firm are used. The corresponding p-values are reported between brackets. ${ }^{* * *}, * *$ and $*$ indicate significance at the $1 \%, 5 \%$ and $10 \%$ levels, respectively.

Panel A: The Choice Between a Dividend Cut and an Optional Stock Dividend

\begin{tabular}{|c|c|c|c|c|c|}
\hline Variables & $\begin{array}{c}\text { (1) } \\
\text { Cut vs OSD }\end{array}$ & $\begin{array}{c}(2) \\
\text { Cut vs OSD }\end{array}$ & $\begin{array}{c}\text { (3) } \\
\text { Cut vs OSD }\end{array}$ & $\begin{array}{c}\text { (4) } \\
\text { Cut vs OSD }\end{array}$ & $\begin{array}{c}\text { (5) } \\
\text { Cut vs OSD }\end{array}$ \\
\hline Cash & $\begin{array}{l}-1.974 \\
(0.268)\end{array}$ & $\begin{array}{l}-1.945 \\
(0.267)\end{array}$ & $\begin{array}{l}-3.272 \\
(0.125)\end{array}$ & $\begin{array}{l}-2.538 \\
(0.158)\end{array}$ & $\begin{array}{l}-1.607 \\
(0.559)\end{array}$ \\
\hline Debt & $\begin{array}{c}0.430 \\
(0.646)\end{array}$ & $\begin{array}{c}0.425 \\
(0.646)\end{array}$ & $\begin{array}{c}1.095 \\
(0.324)\end{array}$ & $\begin{array}{c}1.314 \\
(0.282)\end{array}$ & $\begin{array}{c}2.197 \\
(0.129)\end{array}$ \\
\hline Size & $\begin{array}{c}0.297 * * * \\
(0.000)\end{array}$ & $\begin{array}{c}0.295 * * * \\
(0.000)\end{array}$ & $\begin{array}{c}0.337 * * * \\
(0.000)\end{array}$ & $\begin{array}{c}0.147 \\
(0.158)\end{array}$ & $\begin{array}{l}-0.054 \\
(0.686)\end{array}$ \\
\hline MtoB & $\begin{array}{l}0.275^{*} \\
(0.095)\end{array}$ & $\begin{array}{l}0.279 * \\
(0.097)\end{array}$ & $\begin{array}{c}0.307 \\
(0.120)\end{array}$ & $\begin{array}{c}0.174 \\
(0.456)\end{array}$ & $\begin{array}{l}-0.016 \\
(0.952)\end{array}$ \\
\hline Net Income Variation & $\begin{array}{c}0.892 * * * \\
(0.000)\end{array}$ & $\begin{array}{c}0.889 * * * \\
(0.000)\end{array}$ & $\begin{array}{c}1.036^{* * *} \\
(0.000)\end{array}$ & $\begin{array}{c}1.131^{* * *} \\
(0.000)\end{array}$ & $\begin{array}{c}1.532 * * * \\
(0.000)\end{array}$ \\
\hline Recession & $\begin{array}{c}0.050 \\
(0.888)\end{array}$ & & $\begin{array}{l}-0.044 \\
(0.940)\end{array}$ & $\begin{array}{l}-0.117 \\
(0.870)\end{array}$ & $\begin{array}{c}0.620 \\
(0.446)\end{array}$ \\
\hline Past Dividend Yield & & & $\begin{array}{c}2.081 \\
(0.282)\end{array}$ & & \\
\hline Discount on SEOs (dummy) & & $\begin{array}{c}0.107 \\
(0.769)\end{array}$ & & & \\
\hline Institutional Ownership & & & & $\begin{array}{l}1.871^{*} \\
(0.097)\end{array}$ & \\
\hline Largest Shareholder & & & & $\begin{array}{c}-3.938 * * * \\
(0.000)\end{array}$ & $\begin{array}{c}-3.877^{* * *} \\
(0.001)\end{array}$ \\
\hline Amihud illiquidity Factor & & & & & $\begin{array}{c}-0.960 * * * \\
(0.001)\end{array}$ \\
\hline Constant & $\begin{array}{c}-5.012^{* * *} \\
(0.000)\end{array}$ & $\begin{array}{c}-5.031^{* * *} \\
(0.000)\end{array}$ & $\begin{array}{c}-5.921^{* * *} \\
(0.000)\end{array}$ & $\begin{array}{l}-2.137 \\
(0.221)\end{array}$ & $\begin{array}{c}1.482 \\
(0.497)\end{array}$ \\
\hline Observations & 251 & 251 & 235 & 208 & 207 \\
\hline Year dummies & No & No & Yes & Yes & Yes \\
\hline Industry dummies & Yes & Yes & Yes & Yes & Yes \\
\hline Pseudo R ${ }^{2}$ & 0.249 & 0.250 & 0.322 & 0.370 & 0.430 \\
\hline
\end{tabular}

(Continued on next page) 
Table 4: Logistic Regressions on the Likelihood of Firms Paying Optional Stock Dividends (cont'd)

Panel B: The Choice between a Cash Dividend and an Optional Stock Dividend

\begin{tabular}{|c|c|c|c|c|c|}
\hline Variables & $\begin{array}{c}(6) \\
\text { Cash vs } \\
\text { OSD }\end{array}$ & $\begin{array}{c}(7) \\
\text { Cash vs } \\
\text { OSD }\end{array}$ & $\begin{array}{c}(8) \\
\text { Cash vs } \\
\text { OSD }\end{array}$ & $\begin{array}{c}(9) \\
\text { Cash vs } \\
\text { OSD }\end{array}$ & $\begin{array}{c}(10) \\
\text { Cash vs } \\
\text { OSD }\end{array}$ \\
\hline Cash & $\begin{array}{l}-2.225^{*} \\
(0.059)\end{array}$ & $\begin{array}{l}-2.284^{*} \\
(0.056)\end{array}$ & $\begin{array}{l}-2.349 * \\
(0.074)\end{array}$ & $\begin{array}{l}-1.892 \\
(0.140)\end{array}$ & $\begin{array}{c}-2.166 \\
(0.133)\end{array}$ \\
\hline Debt & $\begin{array}{c}1.556^{* *} \\
(0.014)\end{array}$ & $\begin{array}{c}1.613^{* *} \\
(0.011)\end{array}$ & $\begin{array}{c}1.994^{* * *} \\
(0.003)\end{array}$ & $\begin{array}{c}2.293^{* * *} \\
(0.002)\end{array}$ & $\begin{array}{c}2.122^{* * *} \\
(0.006)\end{array}$ \\
\hline Size & $\begin{array}{l}-0.011 \\
(0.845)\end{array}$ & $\begin{array}{l}-0.013 \\
(0.816)\end{array}$ & $\begin{array}{l}-0.021 \\
(0.716)\end{array}$ & $\begin{array}{c}-0.140^{* *} \\
(0.048)\end{array}$ & $\begin{array}{c}-0.090 \\
(0.231)\end{array}$ \\
\hline MtoB & $\begin{array}{l}-0.233 \\
(0.140)\end{array}$ & $\begin{array}{l}-0.201 \\
(0.205)\end{array}$ & $\begin{array}{l}-0.109 \\
(0.530)\end{array}$ & $\begin{array}{l}-0.190 \\
(0.348)\end{array}$ & $\begin{array}{c}-0.112 \\
(0.561)\end{array}$ \\
\hline Net Income Variation & $\begin{array}{c}0.012 \\
(0.927)\end{array}$ & $\begin{array}{l}-0.012 \\
(0.930)\end{array}$ & $\begin{array}{c}0.142 \\
(0.308)\end{array}$ & $\begin{array}{c}0.153 \\
(0.305)\end{array}$ & $\begin{array}{c}0.143 \\
(0.352)\end{array}$ \\
\hline Recession (dummy) & $\begin{array}{c}0.283 \\
(0.106)\end{array}$ & & $\begin{array}{c}1.557^{* * *} \\
(0.000)\end{array}$ & $\begin{array}{c}1.774^{* * *} \\
(0.000)\end{array}$ & $\begin{array}{c}1.781^{* * *} \\
(0.000)\end{array}$ \\
\hline Past Dividend Yield & & & $\begin{array}{c}8.189 * * \\
(0.037)\end{array}$ & & \\
\hline Discount on SEOs (dummy) & & $\begin{array}{c}0.434^{* * *} \\
(0.010)\end{array}$ & & & \\
\hline Institutional Ownership & & & & $\begin{array}{l}1.166^{*} \\
(0.085)\end{array}$ & \\
\hline Largest Shareholder & & & & $\begin{array}{c}-2.565^{* * *} \\
(0.001)\end{array}$ & $\begin{array}{c}-2.137 * * * \\
(0.004)\end{array}$ \\
\hline Amihud illiquidity Factor & & & & & $\begin{array}{c}0.003 \\
(0.938)\end{array}$ \\
\hline Constant & $\begin{array}{c}-2.471^{* * *} \\
(0.005)\end{array}$ & $\begin{array}{c}-2.621^{* * *} \\
(0.003)\end{array}$ & $\begin{array}{c}-3.989 * * * \\
(0.000)\end{array}$ & $\begin{array}{l}-1.541 \\
(0.237)\end{array}$ & $\begin{array}{l}-1.883 \\
(0.198)\end{array}$ \\
\hline Observations & 1,709 & 1,709 & 1,699 & 1,573 & 1,563 \\
\hline Year dummies & No & No & Yes & Yes & Yes \\
\hline Industry dummies & Yes & Yes & Yes & Yes & Yes \\
\hline Pseudo R² & 0.0877 & 0.0911 & 0.144 & 0.181 & 0.171 \\
\hline
\end{tabular}


Table 5: The Likelihood of Firms Paying Optional Stock Dividends - Matched Samples This table reports the conditional logistic regressions estimating the probability of paying an Optional Stock Dividend (hereafter OSD). The overall sample comprises French listed firms (CAC All Tradable) during the period 2003-2012. Each OSD paying firm is matched with a similar non OSD paying firm, in terms of size, industry (measured as 1-digit SIC Code) and year of payment. In Panel A, each OSD paying firm is matched with a similar dividend cutter, and the dependent variable is a dummy variable that equals 1 in case of an OSD payment and 0 otherwise. In Panel B, each OSD paying firm is matched with a similar cash dividend paying firm, and the dependent variable is a dummy variable that equals 1 in case of an OSD payment and 0 otherwise. Definitions of all variables are reported in the Appendix. Robust standard errors are used. The corresponding $\mathrm{p}$-values are reported between brackets. ${ }^{* * *}$, ** and * indicate significance at the $1 \%, 5 \%$ and $10 \%$ levels, respectively.

\section{Panel A: The Choice between a Dividend Cut and an Optional Stock Dividend - Matched Sample}

\begin{tabular}{lccc}
\hline \multirow{2}{*}{ Variables } & $(1)$ & $(2)$ & $(3)$ \\
Cash & & & \\
& 0.677 & 0.292 & -2.614 \\
Debt & $(0.811)$ & $(0.921)$ & $(0.478)$ \\
& 1.312 & 1.669 & 3.007 \\
Size & $(0.152)$ & $(0.455)$ & $(0.126)$ \\
& $1.152^{* *}$ & 1.745 & $1.994^{*}$ \\
MtoB & $(0.041)$ & $(0.122)$ & $(0.081)$ \\
& -0.089 & $-0.927^{*}$ & -0.800 \\
Net Income Variation & $(0.733)$ & $(0.095)$ & $(0.129)$ \\
& $1.483^{* *}$ & $0.889^{*}$ & 0.587 \\
Largest Shareholder & $(0.027)$ & $(0.055)$ & $(0.296)$ \\
& & $-3.750^{* * *}$ & -1.744 \\
Institutional Ownership & & $(0.008)$ & $(0.392)$ \\
& & $3.240^{*}$ & \\
Amihud illiquidity Factor & & $(0.093)$ & \\
& & & -5.840 \\
& & & $(0.303)$ \\
Observations & & & \\
Year dummies & & & 82 \\
Industry dummies & No & No & No \\
Pseudo R ${ }^{2}$ & No & No & No \\
\hline & 0.390 & 0.506 & 0.571 \\
\hline
\end{tabular}

(Continued on next page) 
Table 5: The Likelihood of Firms Paying Optional Stock Dividends - Matched Samples (cont'd)

Panel B: The Choice between a Cash Dividend and an Optional Stock Dividend Matched Sample

\begin{tabular}{lccc}
\hline \multirow{4}{*}{ Variables } & $(4)$ & $(5)$ & $(6)$ \\
Cash & & & \\
& OSD vs Cash & OSD vs Cash & OSD vs Cash \\
Debt & $-4.251^{* * *}$ & -3.027 & $-4.105^{*}$ \\
& $(0.008)$ & $(0.291)$ & $(0.097)$ \\
Size & $2.506^{* * *}$ & $3.933^{* * *}$ & $3.367^{* * *}$ \\
& $(0.001)$ & $(0.001)$ & $(0.003)$ \\
MtoB & 1.085 & 0.821 & 0.824 \\
& $(0.106)$ & $(0.295)$ & $(0.273)$ \\
Net Income Variation & $-0.379^{* *}$ & $-0.679^{* * *}$ & $-0.456^{* *}$ \\
& $(0.020)$ & $(0.001)$ & $(0.014)$ \\
Largest Shareholder & 0.247 & 0.178 & 0.203 \\
& $(0.148)$ & $(0.420)$ & $(0.358)$ \\
Institutional & & $-2.294^{* *}$ & $-1.673^{* *}$ \\
Ownership & & $(0.015)$ & $(0.040)$ \\
& & & \\
Amihud illiquidity & & $2.968^{* * *}$ & \\
Factor & & $(0.003)$ & \\
& & & -0.114 \\
Observations & & & $(0.271)$ \\
Year dummies & No & No & No \\
Industry dummies & No & No & No \\
Pseudo R & & 0.296 & 0.224 \\
\hline
\end{tabular}




\section{Table 6: Market Reaction to Dividend Announcements}

\section{Panel A: Summary Statistics by Type of Dividend}

This table reports the equity market price reaction to, respectively, Optional Stock Dividend (OSD) announcements, dividend cut (omissions or dividend decreases by more than $30 \%$ for former dividend paying firms) announcements, cash dividend announcements (regardless of the variation of the DPS). The equity market price reaction is computed as the cumulative abnormal returns (CARs) for a particular window around the announcement day. Daily abnormal returns are computed using a market model for the CAC-All Tradable index. Market model parameters are estimated over a 250-day window ending 11 days before the announcement date. Announcement day is denoted as date 0. Patel t-statistics are reported for each series of CARs. T-statistics for the test of difference in means with the subsample of OSDs are reported for each subsample of dividend cuts and cash dividends. ***, ** and * indicate significance of t-statistics at the $1 \%, 5 \%$ and $10 \%$ levels, respectively.

\begin{tabular}{|c|c|c|c|c|c|c|c|c|c|c|}
\hline \multirow[b]{2}{*}{ Type } & \multirow[b]{2}{*}{$\mathrm{N}$} & \multicolumn{3}{|c|}{ CAR[0] } & \multicolumn{3}{|c|}{ CAR $[-1 ; 0]$} & \multicolumn{3}{|c|}{$\operatorname{CAR}[-1 ; 1]$} \\
\hline & & Mean (\%) & T-stat & $\begin{array}{c}\text { Diff. OSD } \\
\text { (t-stat) }\end{array}$ & Mean (\%) & T-stat & $\begin{array}{l}\text { Diff. OSD } \\
\text { (t-stat) }\end{array}$ & Mean (\%) & T-stat & $\begin{array}{l}\text { Diff. OSD } \\
\text { (t-stat) }\end{array}$ \\
\hline Optional Stock Dividend (all) & 166 & 0.30 & $2.30 * *$ & & 0.59 & $2.54 * *$ & & 1.26 & $4.28 * * *$ & \\
\hline \multicolumn{11}{|l|}{ Dividend cuts } \\
\hline All & 145 & -0.69 & $-3.37 * * *$ & $-2.06 * *$ & -0.68 & $-1.98 *$ & $-2.37 * *$ & -0.35 & -0.83 & $-2.38 * *$ \\
\hline Dividend decreases only & 97 & -0.50 & $-1.86^{*}$ & -1.36 & -0.36 & -0.79 & -1.58 & -0.14 & -0.43 & -1.51 \\
\hline Dividend cuts only & 48 & -1.17 & $-3.06 * * *$ & $-1.90 *$ & -1.29 & $-2.32 * *$ & $-2.11^{* *}$ & -1.28 & $-2.05 * *$ & $-2.20 * *$ \\
\hline Cash dividends (all) & 1276 & 0.48 & $9.15^{* * *}$ & 0.67 & 0.64 & $8.96 * * *$ & 0.18 & 1.24 & $13.83 * * *$ & -0.03 \\
\hline
\end{tabular}




\section{Table 6: Market Reaction to Dividend Announcements (cont'd)}

\section{Panel B: Announcement Effect of Optional Stocks Dividends}

This table reports the regression results of abnormal stock returns upon the announcement of a dividend payment. Abnormal stock returns for each dividend announcement are computed as the cumulative abnormal returns (CARs) for a particular window around the announcement day. Daily abnormal returns are computed using market model for the CAC-All Tradable index. Market model parameters are estimated over a 250-day window ending 11 days before the announcement date. Announcement day is denoted as date 0 . Our variable of interest is the OSD dummy that is equal to 1 in case of an Optional Stock Dividend (OSD) payment. Columns (1) to (6) present the results on the subsample of dividend cutters (omissions or dividend decreases by more than $30 \%$ for former dividend paying firms) and firms that switch to an OSD. Columns (7) to (12) present the results on the subsample of optional stock dividend and cash dividend payers. We run both OLS and 2SLS regressions on each subsample. In the 2SLS specifications (i.e. columns (4) to (5) and (10) to (12)), the results for the $2^{\text {nd }}$ stage regressions are reported. The $1^{\text {st }}$ stage regression estimate is the following probit model:

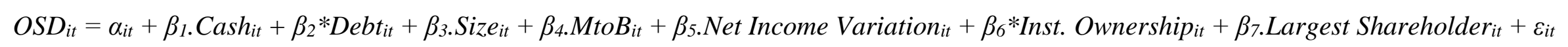

Definitions of all variables are reported in the Appendix. Robust standard errors are used. The corresponding p-values are reported between brackets. ${ }^{* * *}, * *$ and $*$ indicate significance at the $1 \%, 5 \%$ and $10 \%$ levels, respectively.

\section{(Continued on next page)}


Panel B: Announcement Effect of Optional Stocks Dividends (cont'd)

\begin{tabular}{|c|c|c|c|c|c|c|c|c|c|c|c|c|}
\hline \multirow[b]{4}{*}{ Variables } & \multicolumn{6}{|c|}{ Dividend Cuts vs OSD } & \multicolumn{6}{|c|}{ Cash Dividend vs OSD } \\
\hline & (1) & $(2)$ & (3) & (4) & (5) & (6) & (7) & (8) & (9) & (10) & (11) & $(12)$ \\
\hline & \multicolumn{3}{|c|}{ OLS } & \multicolumn{3}{|c|}{2 SLS } & \multicolumn{3}{|c|}{ OLS } & \multicolumn{3}{|c|}{2 SLS } \\
\hline & CAR[0] & CAR $[-1 ; 0]$ & CAR $[-1 ; 1]$ & CAR[0] & CAR $[-1 ; 0]$ & CAR $[-1 ; 1]$ & CAR[0] & CAR[-1;0] & CAR[-1;1] & CAR[0] & CAR $[-1 ; 0]$ & CAR $[-1 ; 1]$ \\
\hline \multirow[t]{2}{*}{ Change in DPS (\%) } & 0.005 & 0.006 & $0.010^{*}$ & 0.008 & 0.004 & 0.017 & $0.008 * * *$ & $0.008 * * *$ & $0.015^{* * *}$ & $0.009 * * *$ & $0.008 * * *$ & $0.011^{* * *}$ \\
\hline & $(0.151)$ & $(0.196)$ & $(0.085)$ & $(0.488)$ & $(0.743)$ & $(0.320)$ & $(0.001)$ & $(0.001)$ & $(0.000)$ & $(0.000)$ & $(0.001)$ & $(0.000)$ \\
\hline \multirow[t]{2}{*}{ OSD } & $0.015^{* *}$ & $0.015^{*}$ & 0.013 & $0.041^{* *}$ & $0.049 * *$ & 0.038 & 0.007 & 0.008 & 0.009 & 0.015 & 0.011 & 0.003 \\
\hline & $(0.039)$ & $(0.074)$ & $(0.183)$ & $(0.019)$ & $(0.015)$ & $(0.136)$ & $(0.114)$ & $(0.113)$ & $(0.134)$ & $(0.357)$ & $(0.546)$ & $(0.918)$ \\
\hline \multirow[t]{2}{*}{ MtoB } & -0.001 & $-0.001 * *$ & -0.000 & -0.000 & -0.001 & 0.001 & 0.000 & -0.000 & 0.000 & 0.000 & -0.001 & 0.000 \\
\hline & $(0.174)$ & $(0.020)$ & $(0.811)$ & $(0.937)$ & (0.733) & $(0.612)$ & $(0.905)$ & $(0.572)$ & $(0.650)$ & $(0.944)$ & $(0.560)$ & $(0.697)$ \\
\hline \multirow[t]{2}{*}{ EBITDA/Assets } & -0.054 & 0.011 & -0.061 & $-0.113^{*}$ & -0.018 & -0.086 & -0.004 & 0.011 & -0.037 & -0.004 & 0.017 & -0.030 \\
\hline & $(0.340)$ & $(0.865)$ & $(0.502)$ & $(0.087)$ & (0.813) & $(0.366)$ & $(0.825)$ & $(0.571)$ & $(0.117)$ & (0.838) & $(0.429)$ & $(0.300)$ \\
\hline \multirow[t]{2}{*}{ Size } & -0.002 & -0.001 & 0.000 & $-0.004^{* *}$ & $-0.003^{*}$ & -0.001 & $-0.001 * * *$ & $-0.001 * * *$ & $-0.002^{* * *}$ & $-0.001^{* *}$ & $-0.001 * *$ & $-0.002^{* * *}$ \\
\hline & $(0.106)$ & $(0.358)$ & (0.936) & $(0.013)$ & $(0.064)$ & $(0.489)$ & $(0.004)$ & $(0.003)$ & $(0.000)$ & $(0.010)$ & $(0.012)$ & $(0.000)$ \\
\hline \multirow[t]{2}{*}{ Constant } & 0.027 & 0.014 & 0.006 & $0.047 * *$ & 0.029 & 0.023 & $0.020 * * *$ & $0.024 * * *$ & $0.048 * * *$ & $0.018^{* *}$ & $0.021^{* *}$ & $0.046^{* * *}$ \\
\hline & $(0.126)$ & $(0.468)$ & $(0.787)$ & $(0.030)$ & $(0.250)$ & $(0.452)$ & $(0.002)$ & $(0.002)$ & $(0.000)$ & $(0.011)$ & $(0.011)$ & $(0.000)$ \\
\hline Observations & 225 & 225 & 225 & 177 & 177 & 177 & 1,346 & 1,346 & 1,346 & 1,162 & 1,162 & 1,162 \\
\hline $\mathrm{R}^{2}$ & 0.044 & 0.037 & 0.034 & & & & 0.021 & 0.022 & 0.036 & & & \\
\hline $\mathrm{Chi}^{2}$ & & & & 13.81 & 11.43 & 7.635 & & & & 103.3 & 98.05 & 105.0 \\
\hline
\end{tabular}


Table 7: Shareholders' Choice between Cash and Stock Dividends

\section{Panel A: Summary Statistics - Shareholder Takeup}

This table reports summary statistics for several classes of discounts at the end of the conversion period. The sample consists of 160 optional stock dividend payments for which we are able to compute the effective shareholder takeup during the period 2003-2012. Definitions of all variables are reported in the Appendix.

\begin{tabular}{lcccc}
\hline Variables & Observations & Mean & Median & Std Dev \\
\hline Discount (End of conversion period) & 145 & 0.085 & 0.081 & 0.104 \\
Takeup & 160 & 0.554 & 0.631 & 0.254 \\
& & & & \\
Takeup And Discount* & & & & \\
$\quad$ Discount $<0 \%$ & 23 & 0.352 & 0.236 & 0.299 \\
$\quad$ Discount $\in[0 \% ; 5 \%[$ & 29 & 0.546 & 0.614 & 0.230 \\
$\quad$ Discount $\in[5 \% ; 10 \%[$ & 30 & 0.569 & 0.632 & 0.234 \\
$\quad$ Discount $\in[10 \% ; 15 \%[$ & 24 & 0.670 & 0.652 & 0.110 \\
$\quad$ Discount $\in[15 \% ; 20 \%[$ & 12 & 0.653 & 0.686 & 0.174 \\
$\quad$ Discount $>20 \%$ & 42 & 0.565 & 0.648 & 0.281 \\
\hline
\end{tabular}




\section{Table 7: Shareholders' Choice between Cash and Stock Dividends (cont'd)}

\section{Panel B: Determinants of Shareholder Takeup}

This table reports the OLS estimation of shareholder takeup in the case of an Optional Stock Dividend (OSD). The sample consists of OSD payments during the period 2003-2012 for which we are able to: (i) compute the effective takeup and (ii) identify the end of the conversion period. GM to Ex-Div is the natural logarithm of the number of days between the General Meeting and the ex-dividend date. Duration of Scrip Option is the natural logarithm of the length in days of the conversion period. Switch to OSD is a dummy that is equal to 1 when a cash dividend paying firm switches to paying an OSD and 0 otherwise. Definitions of all other variables are reported in the Appendix. Robust standard errors are used. The corresponding pvalues are reported between brackets. ${ }^{* * *}, * *$ and * indicate significance at the $1 \%, 5 \%$ and $10 \%$ levels, respectively.

\begin{tabular}{|c|c|c|c|c|c|c|}
\hline Variables & $\begin{array}{c}(1) \\
\text { Takeup }\end{array}$ & $\begin{array}{c}(2) \\
\text { Takeup }\end{array}$ & $\begin{array}{c}\text { (3) } \\
\text { Takeup }\end{array}$ & $\begin{array}{c}\text { (4) } \\
\text { Takeup }\end{array}$ & $\begin{array}{c}\text { (5) } \\
\text { Takeup }\end{array}$ & $\begin{array}{c}\text { (6) } \\
\text { Takeup }\end{array}$ \\
\hline Discount (End of Conversion Period) & $\begin{array}{c}1.734^{* * *} \\
(0.000)\end{array}$ & $\begin{array}{c}1.630^{* * * *} \\
(0.000)\end{array}$ & $\begin{array}{c}1.630 * * * \\
(0.000)\end{array}$ & $\begin{array}{c}1.646 * * * \\
(0.000)\end{array}$ & $\begin{array}{c}1.644^{* * *} \\
(0.000)\end{array}$ & $\begin{array}{c}1.727^{* * *} \\
(0.000)\end{array}$ \\
\hline Size & $\begin{array}{c}0.010 \\
(0.213)\end{array}$ & $\begin{array}{c}0.002 \\
(0.797)\end{array}$ & $\begin{array}{c}0.003 \\
(0.738)\end{array}$ & $\begin{array}{c}0.000 \\
(0.959)\end{array}$ & $\begin{array}{c}0.002 \\
(0.865)\end{array}$ & $\begin{array}{c}0.009 \\
(0.301)\end{array}$ \\
\hline MtoB & $\begin{array}{l}-0.003 \\
(0.880)\end{array}$ & $\begin{array}{c}0.006 \\
(0.795)\end{array}$ & $\begin{array}{c}0.013 \\
(0.526)\end{array}$ & $\begin{array}{c}0.003 \\
(0.894)\end{array}$ & $\begin{array}{c}0.010 \\
(0.634)\end{array}$ & $\begin{array}{c}0.003 \\
(0.893)\end{array}$ \\
\hline Switch to OSD & $\begin{array}{c}0.113^{* *} \\
(0.021)\end{array}$ & $\begin{array}{c}0.109 * * \\
(0.025)\end{array}$ & $\begin{array}{c}0.105^{* *} \\
(0.023)\end{array}$ & $\begin{array}{c}0.119 * * \\
(0.019)\end{array}$ & $\begin{array}{c}0.113^{* *} \\
(0.022)\end{array}$ & $\begin{array}{c}0.118^{* *} \\
(0.017)\end{array}$ \\
\hline Institutional Ownership & $\begin{array}{c}0.299 * * * \\
(0.003)\end{array}$ & $\begin{array}{l}0.192 * \\
(0.077)\end{array}$ & $\begin{array}{c}0.157 \\
(0.136)\end{array}$ & $\begin{array}{c}0.217^{* *} \\
(0.050)\end{array}$ & $\begin{array}{l}0.179 * \\
(0.093)\end{array}$ & $\begin{array}{c}0.272^{* * *} \\
(0.005)\end{array}$ \\
\hline Largest Shareholder & $\begin{array}{c}0.158 \\
(0.135)\end{array}$ & $\begin{array}{c}0.219 * * \\
(0.033)\end{array}$ & $\begin{array}{c}0.210^{* *} \\
(0.037)\end{array}$ & $\begin{array}{c}0.232 * * \\
(0.023)\end{array}$ & $\begin{array}{c}0.221^{* *} \\
(0.026)\end{array}$ & $\begin{array}{c}0.162 \\
(0.113)\end{array}$ \\
\hline Short Term Illiquidity & & $\begin{array}{c}-0.058 * * \\
(0.018)\end{array}$ & $\begin{array}{c}-0.052 * * \\
(0.022)\end{array}$ & $\begin{array}{c}-0.059 * * \\
(0.020)\end{array}$ & $\begin{array}{c}-0.054^{* *} \\
(0.025)\end{array}$ & \\
\hline GM to Ex-Div & & & $\begin{array}{c}0.045^{* *} \\
(0.043)\end{array}$ & & $\begin{array}{l}0.043^{*} \\
(0.059)\end{array}$ & $\begin{array}{c}0.048^{* *} \\
(0.026)\end{array}$ \\
\hline Duration of Scrip Option & & & & $\begin{array}{l}-0.086 \\
(0.358)\end{array}$ & $\begin{array}{l}-0.068 \\
(0.452)\end{array}$ & $\begin{array}{l}-0.067 \\
(0.450)\end{array}$ \\
\hline Constant & $\begin{array}{l}-0.215 \\
(0.159)\end{array}$ & $\begin{array}{c}0.030 \\
(0.871)\end{array}$ & $\begin{array}{l}-0.094 \\
(0.603)\end{array}$ & $\begin{array}{c}0.259 \\
(0.406)\end{array}$ & $\begin{array}{c}0.097 \\
(0.753)\end{array}$ & $\begin{array}{l}-0.139 \\
(0.626)\end{array}$ \\
\hline Observations & 111 & 106 & 106 & 106 & 106 & 111 \\
\hline Year dummies & Yes & Yes & Yes & Yes & Yes & Yes \\
\hline Industry dummies & No & No & No & No & No & No \\
\hline $\mathrm{R}^{2}$ & 0.506 & 0.515 & 0.540 & 0.523 & 0.545 & 0.541 \\
\hline
\end{tabular}


Table 8: Abnormal Volumes and Stock Market Reactions at the Conversion and Issue Dates

This table reports the equity trade abnormal volumes and equity market price reactions to Optional Stock Dividends (hereafter OSD), both at the end of the conversion period and at the effective payment date. Equity trade abnormal volumes are computed as the cumulative abnormal volumes (CAVs) for a particular window. Daily abnormal volumes are computed using an event study approach based on a mean model. We use the natural logarithm of volumes to compute both daily and mean trading volumes. Mean trading volumes are estimated over a 250-day period, ending 11 days before the announcement of an OSD payment. Daily abnormal volumes are computed as the difference between trading volumes on a given date and the relevant mean trading volumes.

The equity market price reaction is computed as the cumulative abnormal returns (CARs) for a particular window around the announcement day, the end of conversion period and the effective payment day. Daily abnormal returns are computed using a market model for the CAC-All Tradable index. Market model parameters are estimated over a 250-day window ending 11 days before the announcement date of an OSD payment. For each characteristic date, the event date is denoted as date 0 . Brown and Warner (Patel) t-statistics are reported for each series of CAVs (CARs). ***, ** and * indicate significance of t-statistics at the $1 \%, 5 \%$ and $10 \%$ levels, respectively.

\begin{tabular}{|c|c|c|c|c|c|c|c|}
\hline \multirow[b]{2}{*}{ Date } & \multirow[b]{2}{*}{$\mathrm{N}$} & \multicolumn{3}{|c|}{ Abnormal Volumes } & \multicolumn{3}{|c|}{ Abnormal Returns (\%) } \\
\hline & & CAV[0] & CAV[-1;0] & CAV[-1;1] & CAR $[0]$ & CAR[-1;0] & CAR[-1;1] \\
\hline Announcement & 166 & $\begin{array}{c}0.353 * * \\
{[2.435]}\end{array}$ & $\begin{array}{c}0.613^{* * *} \\
{[2.991]}\end{array}$ & $\begin{array}{c}1.016^{* * *} \\
{[4.046]}\end{array}$ & $\begin{array}{c}0.299 * * \\
{[2.296]}\end{array}$ & $\begin{array}{l}0.599 * * \\
{[2.368]}\end{array}$ & $\begin{array}{c}1.264 * * * \\
{[4.284]}\end{array}$ \\
\hline Ex-dividend & 166 & $\begin{array}{c}0.558 * * * \\
{[3.853]}\end{array}$ & $\begin{array}{c}1.056 * * * \\
{[5.153]}\end{array}$ & $\begin{array}{c}1.187 * * * \\
{[4.728]}\end{array}$ & $\begin{array}{l}0.299 * * \\
{[2.296]}\end{array}$ & $\begin{array}{l}0.599 * * \\
{[2.368]}\end{array}$ & $\begin{array}{c}1.264 * * * \\
{[4.284]}\end{array}$ \\
\hline End of conversion period & 144 & $\begin{array}{c}0.535 * * * \\
{[3.54]}\end{array}$ & $\begin{array}{c}0.741 * * * \\
{[3.468]}\end{array}$ & $\begin{array}{c}0.909 * * * \\
{[3.476]}\end{array}$ & $\begin{array}{c}-0.278 \\
{[1.599]}\end{array}$ & $\begin{array}{c}-0.571^{* *} \\
{[2.443]}\end{array}$ & $\begin{array}{c}-0.362 * \\
{[1.735]}\end{array}$ \\
\hline $\begin{array}{l}\text { Effective payment } \\
\text { All events }\end{array}$ & 166 & $\begin{array}{c}0.257 * \\
{[1.776]}\end{array}$ & $\begin{array}{l}0.442 * * \\
{[2.157]}\end{array}$ & $\begin{array}{c}0.833^{* * *} \\
{[3.318]}\end{array}$ & $\begin{array}{l}-0.037 \\
{[0.05]}\end{array}$ & $\begin{array}{c}0.204 \\
{[0.808]}\end{array}$ & $\begin{array}{c}0.117 \\
{[0.134]}\end{array}$ \\
\hline End of conversion available & 144 & $\begin{array}{c}0.204 \\
{[1.353]}\end{array}$ & $\begin{array}{l}0.437 * * \\
{[2.044]}\end{array}$ & $\begin{array}{c}0.805^{* * *} \\
{[3.079]}\end{array}$ & $\begin{array}{c}-0.013 \\
{[0.275]}\end{array}$ & $\begin{array}{c}0 \\
{[0.001]}\end{array}$ & $\begin{array}{c}-0.037 \\
{[0.039]}\end{array}$ \\
\hline
\end{tabular}


Figure 1: The Timeline of an Optional Stock Dividend (OSD) Payment - The Example of Sanofi (2011)

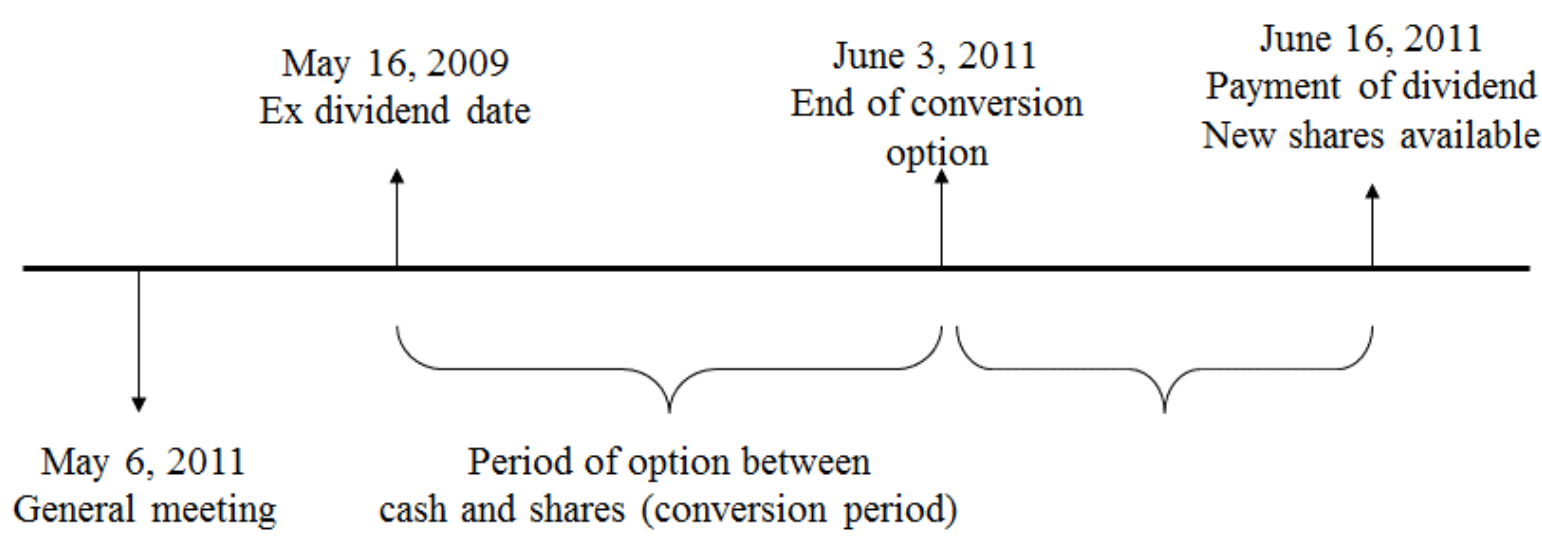

Figure 2: Sanofi's presentation of its dividend per share (in €) over the period 2004-2013

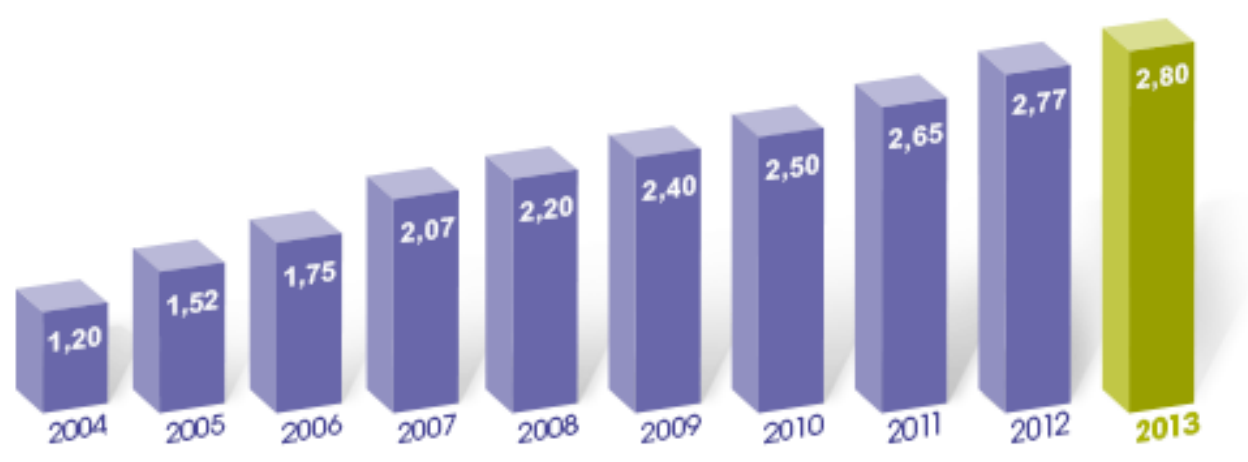

Source: Sanofi website, October 2014

An optional stock dividend has been offered in 2011 (dividend per share 2010, 2.50€), but the firm presents the historical series of dividends without mentioning the stock dividend, neither on the website, nor in the reference documents of the following years. 